\title{
Reconstruction of tectonically disrupted carbonates through quantitative microfacies analyses: an example from the Middle Triassic of Southern Italy
}

\author{
Adriano Guido ${ }^{1}$. Giuseppe Palladino ${ }^{2,3} \cdot$ Matteo Sposato $^{1} \cdot$ Franco Russo $^{1} \cdot$ Giacomo Prosser $^{2} \cdot$ Mario Bentivenga $^{2}$. \\ Adelaide Mastandrea ${ }^{1}$
}

Received: 29 January 2021 / Accepted: 26 May 2021 / Published online: 3 June 2021

(c) The Author(s) 2021

\begin{abstract}
The main goal of the paper is the reconstruction of a Middle Triassic buildup cropping out in the central part of the Southern Apennines. Middle Triassic reefs of the western Tethys realm are well known in the Northern and Southern Alps. In contrast, few studies of the Anisian-Ladinian carbonate platforms of the southern Apennines are available, due to the diagenetic alteration and tectonic disruption that hinder their paleoenvironmental and stratigraphic reconstruction. In an attempt to fill this gap, and to improve the knowledge on the Anisian-Ladinian carbonates of central Mediterranean area, this research is focused on a carbonate buildup cropping out in the "La Cerchiara" area, Sasso di Castalda (Basilicata, Southern Italy). The buildup, affected by intense tectonic deformation associated with the development of the Apennine thrust and fold belt, was studied using a statistical evaluation of the quantitative microfacies data. The research enabled a reconstruction of the original stratigraphic relationships of the various buildup fragments. A positive linear regression between the sample positions vs the percentage of autochthonous carbonates indicates an increase of the autochthons carbonate toward the top of the succession. The allochthonous fabrics (packstone/wackestone) at the base of the section (Unit IIIa) pass gradually upward into autochthonous (boundstones) facies (Units IIIb, I), consisting of microbialites (clotted peloidal micrite, microbial-derived laminae, and aphanitic micrite), microproblematica and cyanobacterial crusts, with few encrusting skeletal organisms. Statistical data suggest that units IIIa, IIIb, and I are in stratigraphic order while unit II appears to have been moved by tectonic dislocation from its original position at the base of the succession. The absence of metazoan reef framework, and the richness of micro-encrusters, autochthonous micrite and synsedimentary cements, suggest a mud-mound style of growth for the carbonate bodies of the Southern Apennine during the Anisian.
\end{abstract}

Keywords Microbialites $\cdot$ Cyanobacterial crusts $\cdot$ Microproblematica $\cdot$ Buildup $\cdot$ Tectonic disruption $\cdot$ Anisian

\section{Introduction}

Adriano Guido

aguido@unical.it

1 Department of Biology, Ecology and Earth Sciences, University of Calabria, Via Pietro Bucci, Cubo 15b, 87036 Rende, Cosenza, Italy

2 Dipartimento di Scienze, Università degli Studi della Basilicata, Viale dell'Ateneo Lucano, 10, 85100 Potenza, Italy

3 Geology and Petroleum Geology, University of Aberdeen, Aberdeen, UK
Mass extinction at the P/T boundary caused a sharp decrease in carbonate production, inducing a stasis in reef development (Sheehan 1985; Stanley 1988; Flügel 1994; Webb 1996; Enos et al. 2006; Minzoni et al. 2015). Therefore, Early Triassic carbonates were essentially characterized by a higher amount of microbialites than the end-Permian metazoan reefs (Sheehan and Fagerstrom 1988; Baud et al. 1997, 2007; Lehrmann 1999; Pruss et al. 2006; Brayard et al. 2011; Kershaw et al. 2012; Heindel et al. 2018; Martindale et al. 2019). Following this phase, during the Middle Triassic, the establishment of suitable carbonate environments, together with the recurrence of reefal skeletal organisms, allowed reefs to re-flourish (Flügel 1982, 2002; Velledits 1999, 2008; 
Velledits et al. 2011). During early-middle Anisian, the slow restoration of the carbonate producers led to the formation of buildups in which the contribution of skeletal organisms was minor in comparison with the microbial bio-induced component, which was indispensable for their growth.

Triassic reefs have been widely studied in the Dolomites, where, from Anisian through Carnian times, low-relief terrigenous-carbonate ramps, rich in loose micritic mud, evolved into isolated high-relief carbonate buildup, dominated by automicrite and syndepositional cements (Biddle 1981; Gaetani et al. 1981; Brandner et al. 1991; Harris 1993, 1994; Blendinger 1994, 1996; Keim and Schlager 1999, 2001; Emmerich et al. 2005; Russo 2005; Stefani et al. 2010; Marangon et al. 2011; Guido et al. 2016, 2018, 2019). Anisian buildups generally lack primary metazoan framework and evidence of strong syndepositional cementation (Bosellini and Rossi 1974; Cros 1974), whereas late Anisian-early Ladinian buildups are dominated by autochthonous micrite, calcimicrobes, microproblematica, and synsedimentary cements (Bechstädt and Brandner 1970; Brandner and Resch 1981; Gaetani et al. 1981; Brandner et al. 1991, 2007, 2012; Russo 2005; Seeling et al. 2005; Brandner and Keim 2011). Late Ladinian and Carnian platforms, developed after a Ladinian volcanic event, consist mainly of micrites, cements and subordinately skeletons (Bosellini 1984; Blendinger 1994; Russo 2005; Stefani et al. 2010). Automicrites make up the main constituent of the late Ladinian-Carnian carbonates, accounting for the 50\% of the rock volume, whereas cements amount to $20 \%$, and skeletal remains to less than the $10 \%$ (Russo 2005; Stefani et al. 2010). Metazoan skeletons are subordinate comparing to microproblematica and microbial-induced carbonates. During the Carnian, small calcareous bioconstructions, interpreted as patch reefs, show similarity with modern bioconstructions, constituted of a primary calcified demosponge and scleractinians skeletal framework (Russo 2005; Stefani et al. 2010). Taxonomic diversity increased greatly, and the skeletal components exceed 50\% of the rock volume (Russo 2005; Stefani et al. 2010).

Western Tethyan Anisian-Ladinian reefs are well known from the Northern and Southern Alps and from Hungary (Flügel 2002; Velledits et al. 2011), whereas only very few studies have been focused on the Middle Triassic reefs exposed in the Southern Apennines and in general in Central Mediterranean area. In the study area, paleontological, sedimentological and structural studies were addressed to the characterization of the Monte Facito Formation cropping out in Basilicata, but they have not adequately defined the geometry, structure and paleoenvironmental evolution of the carbonate bodies, due to the late dolomitization, intense tectonic deformation, and faulting (Scandone 1967; Donzelli and Crescenti 1970; Wood 1981; Ciarapica et al. 1986, 1990a; b, c; Panzanelli Fratoni et al. 1987; Miconnet 1988;
Rettori et al. 1988; Martini et al. 1989; Ciarapica 1990; Panzanelli Fratoni 1991; Marsella et al. 1993; Ciarapica and Passeri 2000; Palladino 2015; Palladino et al. 2019).

Rare exposures of not-dolomitized carbonate bodies provide unique opportunity for studying the Middle Triassic buildups, in the central Mediterranean area. Among them, the carbonate units exposed at "La Cerchiara" (Basilicata, Southern Apennines; Figs. 1 and 2) provide a key contribution to the reconstruction of the type, paleoecology and paleoenvironmental evolution of the Anisian-(?)Ladinian buildups of this area. Characterization of their microfacies through quantitative analyses has allowed us to: (a) reveal the main constituents involved in the buildup growth; (b) distinguish the roles of metazoan vs microbialites in the carbonate production; (c) evaluate the depositional textures (autochthonous vs allochthonous); (d) correlate the microfacies variation with the depositional geometries; (e) reconstruct the paleoenvironment evolution of the buildup; and (f) compare the buildup with coeval carbonate platforms of the Tethys realm.

\section{Geological setting}

The "La Cerchiara" succession $\left(40.509317^{\circ} \mathrm{N}, 15.694757^{\circ}\right.$ E), located in the area of Sasso di Castalda (Basilicata) (Figs. 1 and 2), is one of the most representative outcrop of the Early-Middle Triassic Monte Facito Formation (Scandone 1967; Wood 1981; Ciarapica et al. 1990a, b, c; Palladino 2015; Palladino et al. 2019). The Monte Facito Formation is a composite stratigraphic unit, consisting of isolated platform limestone slabs, fine- to medium-grained siliciclastic rocks, and radiolarites, which accumulated during the opening of the Lagonegro basin (Patacca and Scandone 2007). According to several authors (Finetti et al. 1996; Ciarapica and Passeri 2002; Stampfli and Borel 2002), the development of this basinal area was connected to the evolution of the late Permian-Early Triassic Ionian Sea, representing the northeastern prolongation of the Neo-Tethyan Oceanic domain. Other authors argue that the Lagonegro was an independent basin, not connected to the Tethys (Scotese and Schettino 2017; van Hinsbergen et al. 2020). Due to later tectonic processes, the original basement that hosted the sedimentation of the Monte Facito Formation is unknown (Patacca and Scandone 2007). For this reason, the determination of its original position above a possible continental or oceanic crust represents an unsolved problem in the geology of the Southern Apennines (Argnani 2013).

The Monte Facito Formation lies at the stratigraphical base of the Lagonegro Basin succession, which also includes the Calcari con Selce (Late Triassic), Scisti Silicei (Late Triassic-Jurassic), Galestri (Cretaceous) and Flysch Rosso (Cretaceous-Oligocene) formations (Scandone 1967, 1972; 

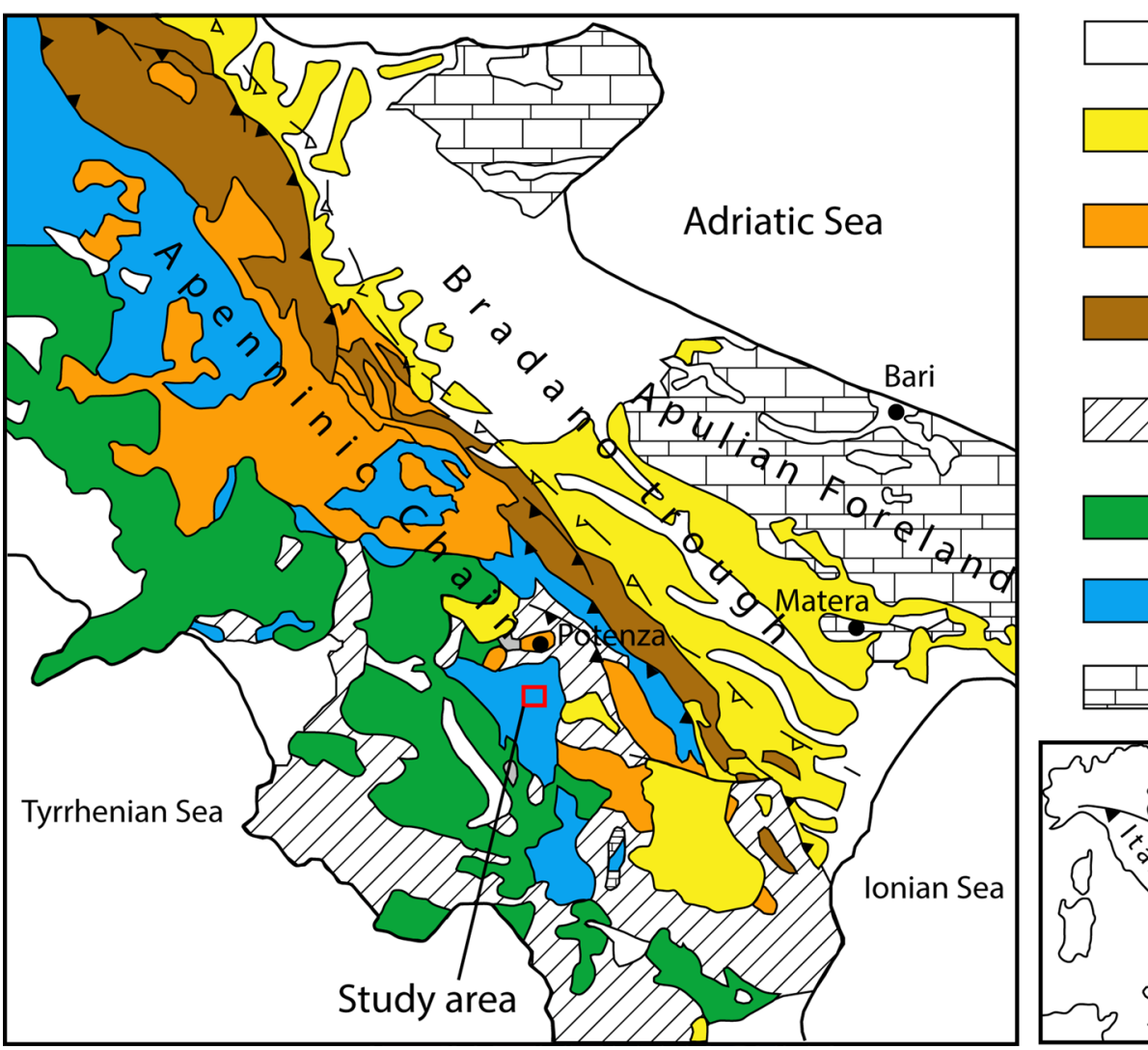

Continental and volcanic deposits (Middle Pleistocene - Holocene)

Marine to continental deposits (Late Pliocene - Middle Pleistocene)

Thrust-sheet-top deposits (Late Tortonian - Late Pliocene)

Southern Apennine front deposits (Early-Late Miocene)

Liguride-Sicilide nappes and related thrust-top-sheet deposits (Jurassic-Oligocene)

Campano-Lucana Platform deposits (Late Triassic-Middle Miocene)

Lagonegro Basin deposits (Early Triassic-Late Miocene)

Apulian Platform deposits (Permian-Pleistocene)

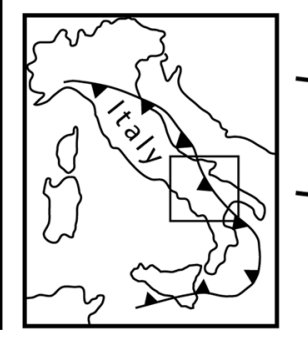

\section{Main out-of-sequence thrust \\ Buried Apenninic thrust front}

Fig. 1 Simplified geological map of the Southern Apennine thrust-belt in the Campano-Lucano sector, showing the location of the study area. Modified from Patacca et al. (1992)

Donzelli and Crescenti 1970; Wood 1981; Ciarapica et al. 1988, 1990c; Miconnet 1988; Martini et al. 1989; Panzanelli Fratoni 1991; Marsella et al. 1993; Ciarapica and Passeri 2000; Passeri and Ciarapica 2010).

After deposition, the Lagonegro Basin succession has been affected by intense contractional deformation during the Miocene building of the Southern Apennines thrust and fold belt. This process led to the detachment of the Monte Facito Formation from its original basement, along a lowangle regional thrust surface, which is responsible for the general doubling of the Lagonegro Basin units, identified, respectively, as Lagonegro Unit I, located at the footwall of the thrust, and Lagonegro Unit II, at its hanging wall (Scandone 1972). During Early Pleistocene, the tectonic regime in the Apennine chain changed from contractional to extensional, as testified by the presence of strike-slip and normal faults, crosscutting pre-existing thrusts and folds (Bucci et al. 2014).

The Monte Facito Formation is commonly defined as a chaotic complex and it is often considered as a sedimentary mélange (Wood 1981; Marsella et al. 1993; Patacca and Scandone 2007; Palladino 2015; Palladino et al. 2019). The main evidence for this interpretation is the frequent presence of carbonate olistoliths and disrupted strata within a clayey and silty matrix (Ciarapica and Passeri 2000; Passeri and Ciarapica 2010). According to Palladino (2015), emplacement of sedimentary mélange followed the formation of carbonate build-ups of Early Ladinian age. Mélange deposits are thought to record diffuse land-sliding phenomena connected to the initial continental break-up of the Adria plate and to the opening of the Lagonegro Basin, starting from the Ladinian (Marsella et al. 1993; Patacca and Scandone 2007). More recent studies demonstrated that the current configuration of the Monte Facito Formation has been produced by a more complex evolution, resulting from a contractional tectonic overprint on an already chaotic Middle Triassic sedimentary mélange (Palladino et al. 2019).

\section{The "La Cerchiara" succession}

The "La Cerchiara" outcrops are roughly E-W oriented and expose an about $1400 \mathrm{~m}$ thick succession consisting of carbonate units alternating with basinal shales, followed by paraconglomerates and deep-water deposits (shales and radiolarian cherts) (Fig. 3). The studied section starts with shallow-water carbonates, organized in tens of metersthick units separated by laminated deep-water yellow and red shales (Fig. 4). This first interval, known in the 


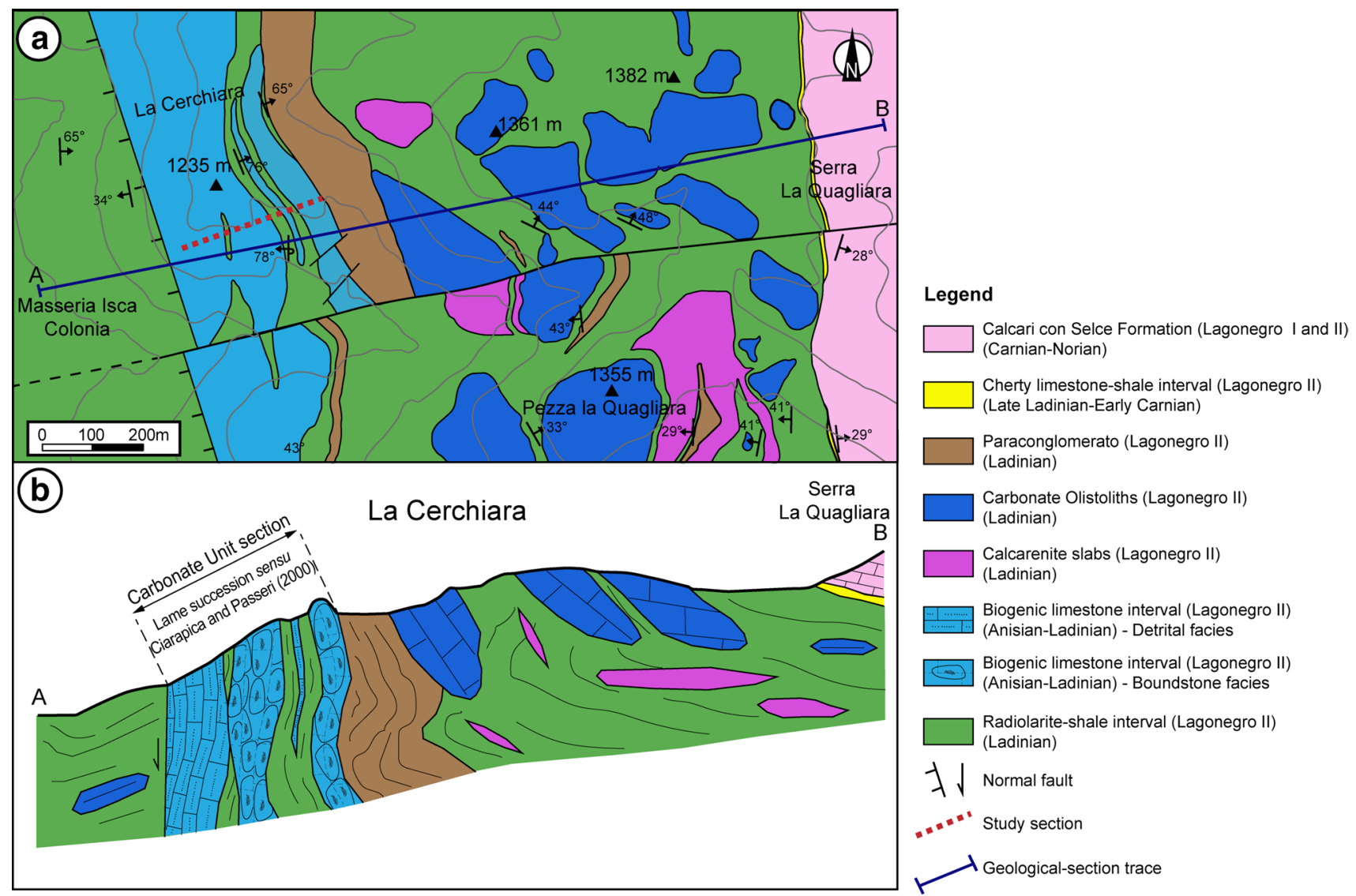

Fig. 2 a Detailed geological map showing the different units of the Monte Facito Formation outcropping at "La Cerchiara". The studied stratigraphic section, illustrated in Fig. 4, is indicated by a red dotted line. b Geological cross section

geological literature as the "Lame succession" (Ciarapica and Passeri 2000), shows an average thickness of $300 \mathrm{~m}$ and represents the main topic of our research. The age of the carbonate sequence has been doubtfully attributed to late Anisian-early Ladinian, on the basis of the algae, foraminifers, conodonts and calcareous sponge association (Scandone 1967; Panzanelli Fratoni et al. 1987; Miconnet 1988; Rettori et al. 1988; Martini et al. 1989; Ciarapica 1990; Ciarapica et al. 1990a, b, c; Panzanelli Fratoni 1991; Marsella et al. 1993; Ciarapica and Passeri 2000). The exact chronostratigraphic attribution is however not clearly defined, due to the contradictory data reported by various authors. The uncertainty mainly derives from the absence of accurate biostratigraphic markers and from the significant fragmentation of the carbonate bodies. In particular, the eastern build-up body (Unit I, see Fig. 3) was tentatively dated to the Anisian-Lower Ladinian transition (Illirian-Fassanian) for the presence of the conodont Paragondolella alpina szaboi (Ciarapica and Passeri 2000), whereas the western one (Units IIIa and IIIb, see Fig. 3) was attributed to a generic Ladinian for the presence of the foraminifers Lamelliconus procerus and Lamelliconus ex gr. ventroplanus which excludes a reference to Anisian (Ciarapica and Passeri 2000).

Although uncertainties remain, the abundance of microbialites, calcimicrobe crusts and microproblematica, very similar to the typical Anisian carbonate succession of the Southern Alps (Gaetani et al. 1981; Gaetani and Gorza 1989), suggests referring the studied carbonate units with the latter ones. The succession continues eastward with about $100 \mathrm{~m}$ brown shales, alternating with turbiditic sandstones and conglomerates, dated as late Ladinian (Ciarapica and Passeri 2000). The remaining portion of the succession, about 300-400 m thick, mainly consists of shales and radiolarites, comprising olistoliths, breccias and slide deposits (late Ladinian). The final part of the succession consists of alternating pelagic limestones and shales that characterize the transition toward the overlying "Calcari con Selce" Formation.

Our study is focused on quantitative microfacies characterization of the carbonate units in the "La Cerchiara" succession (Figs. 2, 3, and 4). The limestones were affected here by an initial phase of diagenetic recrystallization, but not affected by dolomitization that hampers the microfacies 

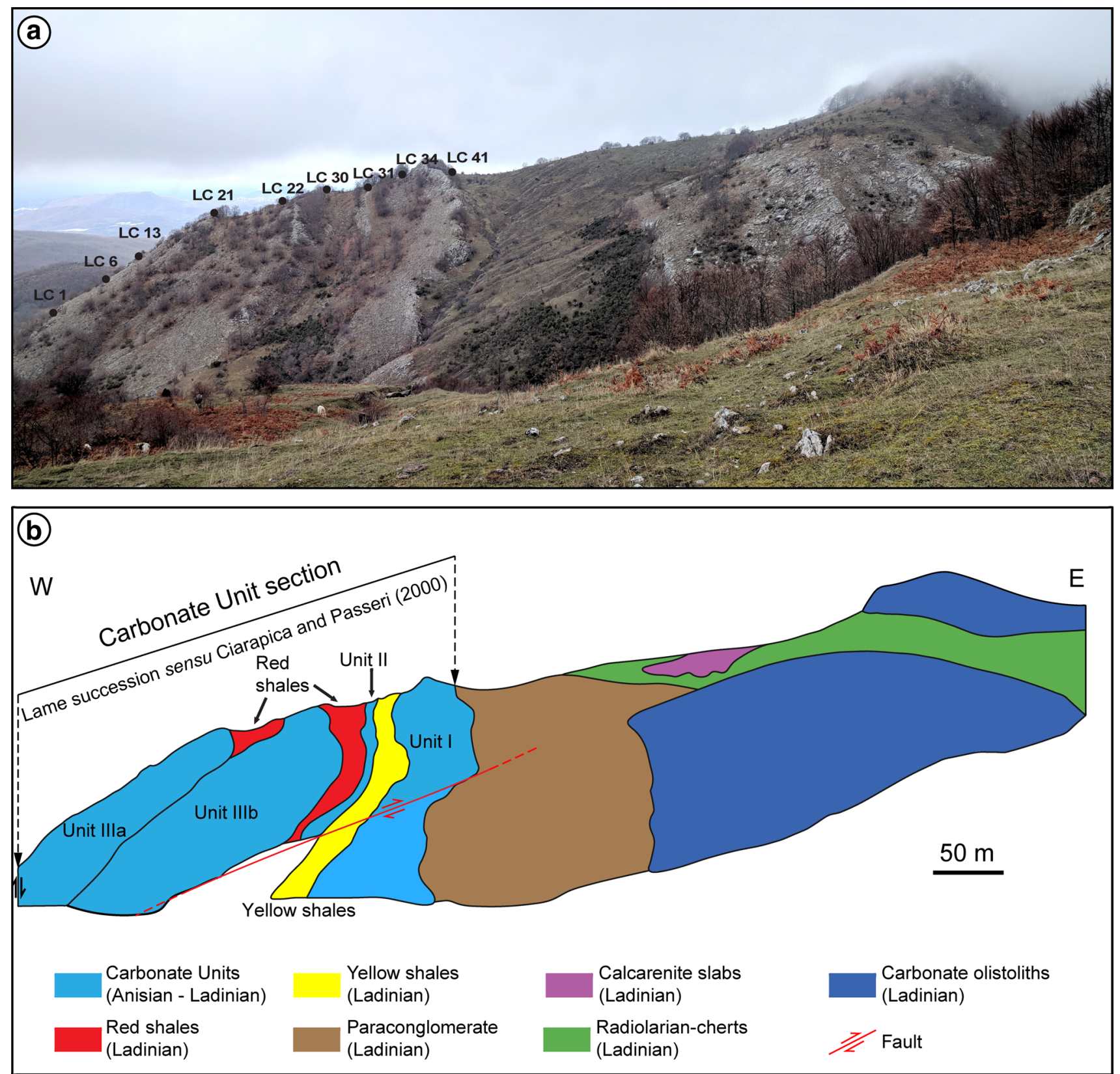

Fig. 3 a Panoramic view of the "La Cerchiara" succession with the locations of samples collected from the carbonate units. b Simplified line drawing showing the distribution of the main sediment units. In

study of some of the carbonates outcropping in the region. Tectonic overprint is outlined by large-scale folding of the carbonate units, showing steeply dipping upright and locally overturned beds. This deformation challenges reliable geometric, stratigraphic and paleoenvironmental reconstructions. The complex tectonic setting led previous authors to formulate opposing interpretations of the younging direction of the "La Cerchiara" succession. Based on field observations, Scandone (1967) and Wood (1981) inferred an eastward younging, whereas Ciarapica and Passeri (2000) the carbonate unit section, boundaries separating Units IIIa, IIIb, II, I, red shales and yellow shales are interpreted as uncertain tectonic contacts

proposed westward younging, as suggested by paleontological data. More recently, support for eastward younging of the "La Cerchiara" succession was provided by Palladino (2015) on the basis of sedimentological criteria.

The base of the succession coincides with a normal fault that forms the western boundary of the carbonate succession (Fig. 2). The four carbonate intervals, here identified as Units, have been termed "Lame" by Ciarapica and Passeri (2000), who provided also the age estimates, based on foraminifera and conodonts content. The base of the 


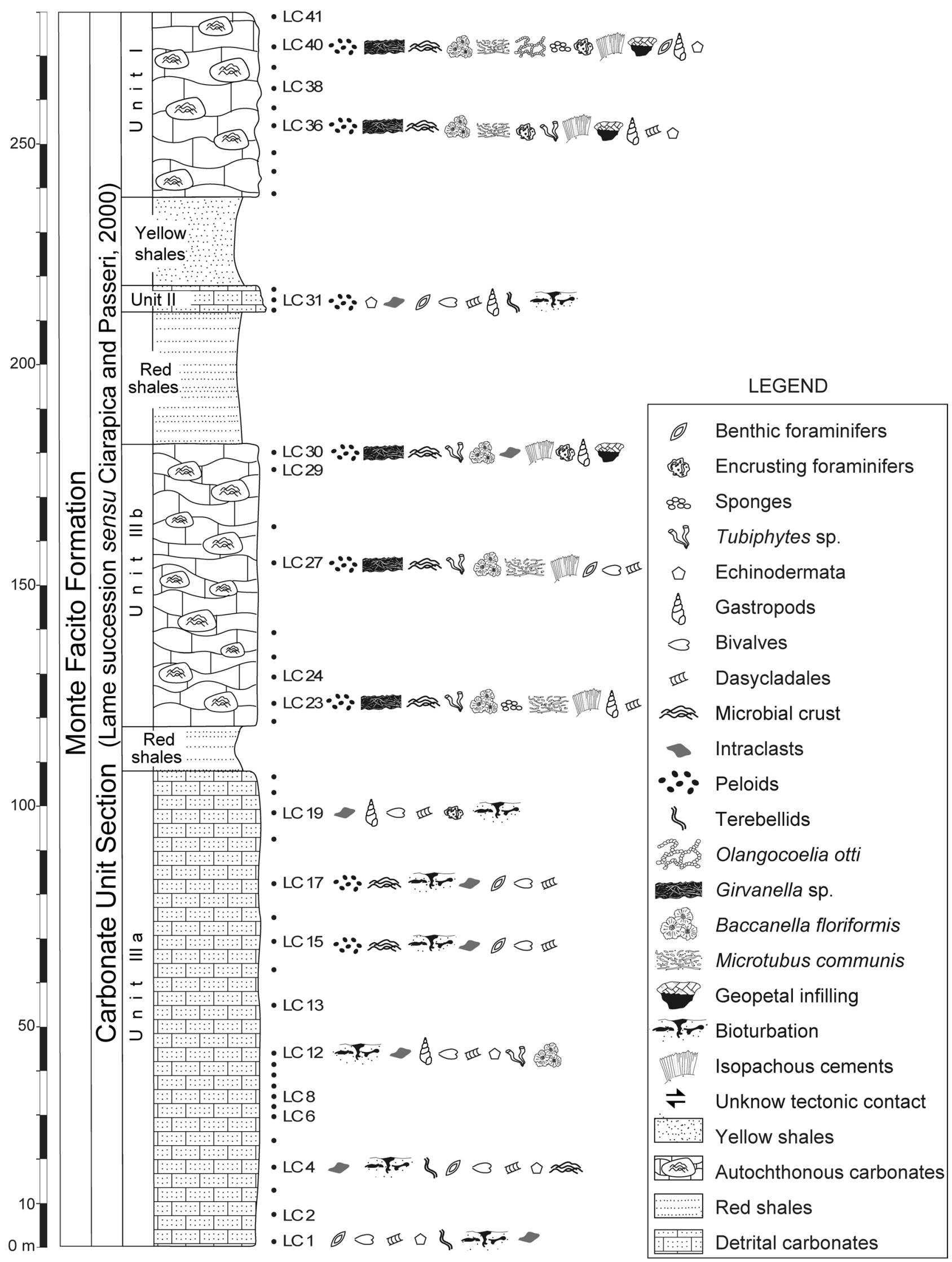


4Fig. 4 Geological profile with the locations of the samples. Only the samples utilized for quantitative analyses are indicated with numbers. The distribution of the main skeletal and non-skeletal component is showed only for some of the samples. The relative abundance of these components varies along the section. Detrital carbonates characterize the lower part of the succession (Unit IIIa and Unit II), whereas autochthonous carbonates predominate in Unit IIIb and Unit I. In the Carbonate Unit section, boundaries separating Units IIIa, IIIb, II, I, red shales and yellow shales are interpreted as uncertain tectonic contacts

succession consists of two superimposed planar-bedded carbonate bodies, 110 and $64 \mathrm{~m}$ thick, here identified as Unit IIIa and Unit IIIb (Figs. 3 and 4). Foraminifera content suggests a generic Ladinian for this carbonate body. These two Units, interpreted by Ciarapica and Passeri (2000) as a tectonic duplication of the same carbonate unit, are separated by a $10 \mathrm{~m}$ thick red shale interval. The succession continues upward with $20 \mathrm{~m}$ of red shales, characterized by a poor paleontological content, similar to the interval occurring between Unit IIIa and IIIb. The subsequent Unit II, attributed to a generic Ladinian, consists of a thin carbonate body ( $6 \mathrm{~m}$ thick) that pinches out northward and is separated from Unit I by $20 \mathrm{~m}$ of yellowish shales, dubiously dated to Fassanian?- early Longobardian? using conodonts content. Unit I, representing the uppermost carbonate body of the studied section, is $42 \mathrm{~m}$ thick and it is attributed to an Illirian-Fassanian according to conodonts content (Figs. 3 and 4).

\section{Methods and studied materials}

The four carbonate Units (I, II, IIIa and IIIB) were sampled in detail for microfacies analyses as follows: 30 samples from Unit III, 3 samples from the Unit II, and 8 samples from the Unit I (Figs. 3 and 4). Two thin sections, one perpendicular and one parallel to the bedding plane, were prepared from each sample. Microfacies characterization was performed with an optical microscope (Zeiss Axioplan Imaging II) under plane and cross-polarized light. Quantitative analyses of the microfacies were performed by point counting 24 polished thin sections. A grid with a $0.5 \mathrm{~mm}$ count step was used to count 400 points for each thin section, following the grain counting methodology described in Flügel (2010). The percentage of the various components was automatically obtained using a Counter AC-15 apparatus.

Epifluorescence observations were used to detect the distribution of the organic matter, with incident light emitted by a $\mathrm{Hg}$ high-pressure vapor bulb attached to Axioplan Imaging II microscope (Zeiss), equipped with high-performance wide bandpass filters (BP 436/10 nm/LP 470 nm, no. 488 006, for green light; and BP 450-490 nm/LP 515 nm, no. 488009, for yellow light).

Micro/nano-morphological studies were carried out with an FEI-Philips ESEM-FEG Quanta 200F Scanning Electron Microscope (SEM) on freshly broken samples, polished surfaces, or thin sections. In the last two cases, the observed surfaces were prepared with 0.25 micron diamondimpregnated grinding paper, then gently etched $(0.05 \% \mathrm{HCl}$, $1 \mathrm{~min}$ ). The samples were then carbon- or gold-coated (ca. $250 \AA$ A coating thickness). SEM working conditions were as follows: accelerating voltage of $15 \mathrm{kV}$, working distance between 10 and $15 \mathrm{~mm}$.

Mineralogical and chemical analyses were obtained using an Electron Probe Microanalyzer (EPMA), JEOL- JXA 8230 on polished surfaces or thin sections, prepared with the same procedure as for SEM observations, but without the carbon or gold coating. EPMA working conditions were as follows: voltage $15 \mathrm{keV}$, Probe current $10 \mathrm{nA}$, Working Distance $11 \mathrm{~mm}$, Take-off angle $40^{\circ}$, Live Time $50 \mathrm{~s}$.

\section{Results and analyses}

\section{Field observations}

The carbonate Unit interval of "La Cerchiara" succession consists of carbonates and shales (Fig. 2). The carbonates are organized in four irregular-shaped bodies (Units), with thicknesses of the strata from tens of centimeters up to few meters (Figs. 3 and 4). They show bedding from planar, as in Unit IIIa and Unit II, to massive, as in Unit IIIb and I. The carbonates are light gray in color and show very finely crystalline matrix. Only larger grains, representing fragments of dasycladacean algae and intraclasts, are generally visible. Millimetric- to centimetric-sized cavities commonly occur, which are occluded by generations of isopachous and sparry cements. These cavities often contain yellowish material interpreted as fine-grained dolomite by Ciarapica and Passeri (2000).

\section{Thin-section analyses}

\section{Carbonate components}

The microfacies of the carbonate Units consist of boundstones and subordinately packstones, wackestones and grainstones. The boundstones are composed of encrusting organisms (calcimicrobs, foraminifers and microproblematica), green algae (Dasycladales) and calcisponges (Sphinctozoa). A high amount of autochthonous micrite is also present. It occurs as very fine-grained laminations, varying in size from few microns to tens of microns. The laminae generally encrust lithoclasts of reworked boundstone, skeletal 

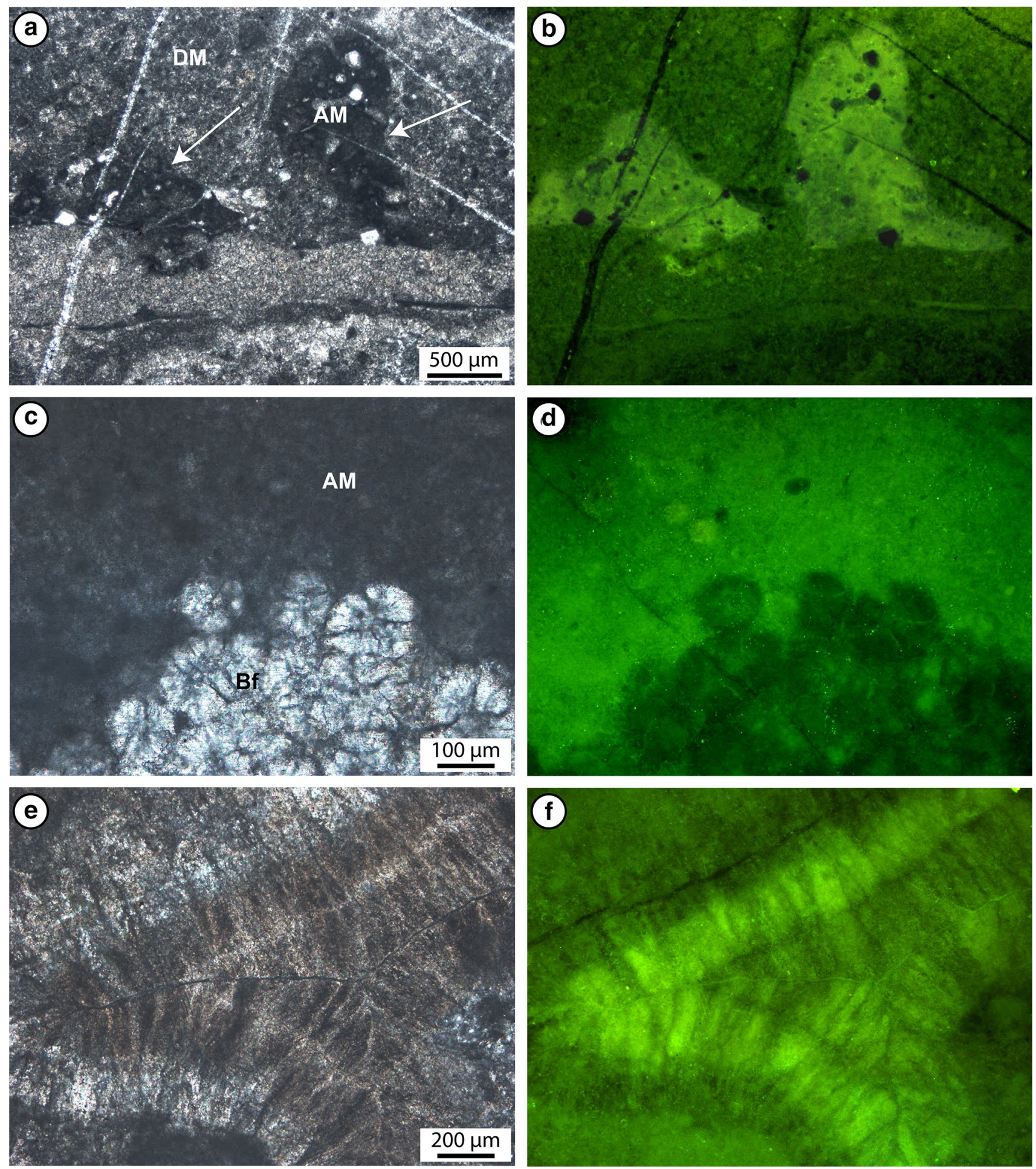

Fig. 5 Micrites and cements observed in transmitted (left) and ultraviolet light (right). Autochthonous micrite (AM), that form microcolumns on skeletal substrates (white arrows) (a), or present as structureless material around the grains (c), show bright epifluorescence (b, d), revealing high organic matter content. Detrital micrite (DM),

on the upper part of photograph (a), appears dark in color under ultraviolet light (b). Bf Baccanella floriformis. e, f Early cement observed in transmitted (left) and ultraviolet light (right). These cements are characterized by alternation of cloudy (epifluorescent) and whitish bands. a Sample LC25; c sample LC25; e sample LC 38 

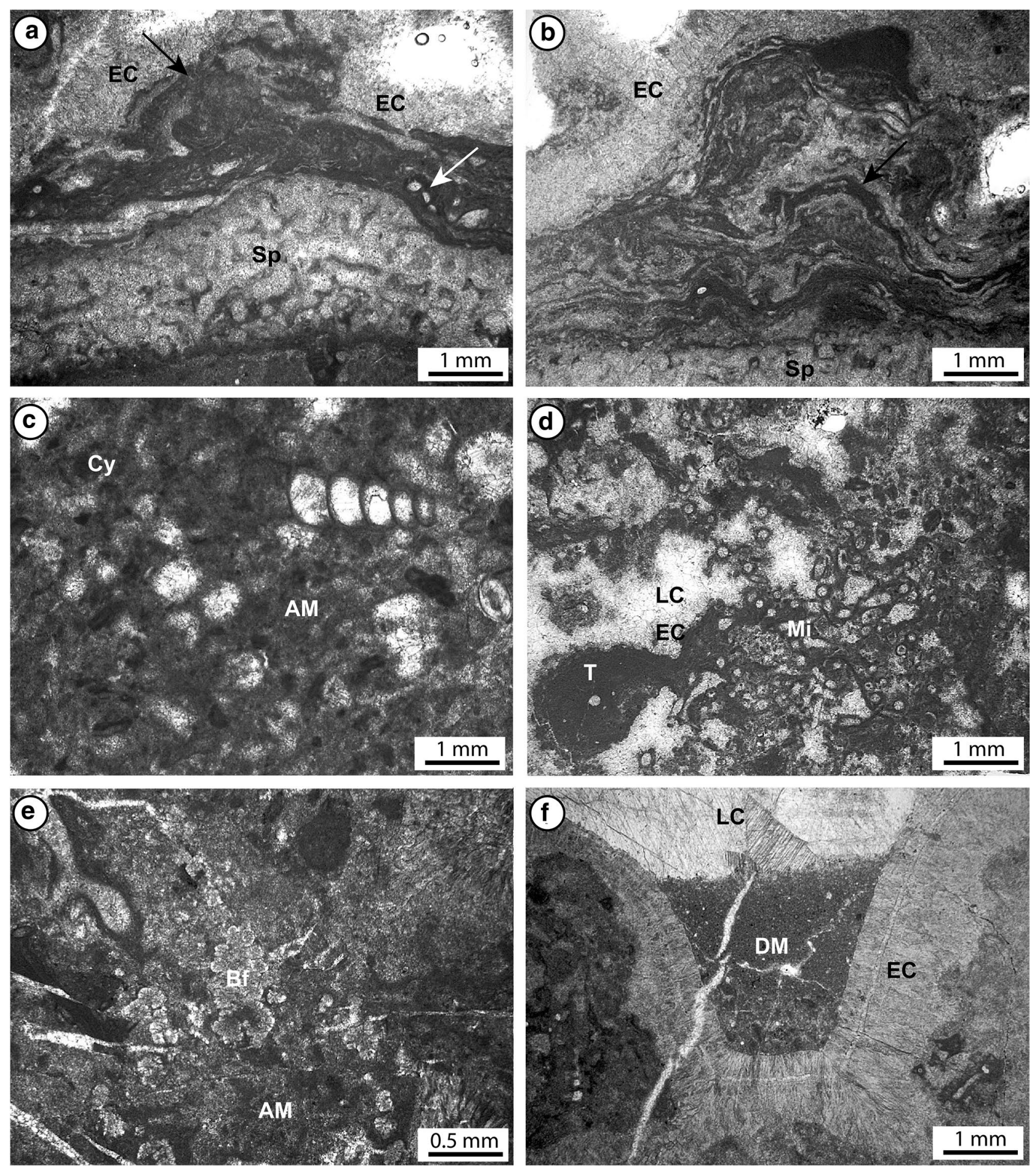

Fig. 6 a-e Microfacies of Unit I, composed mainly of autochthonous micrite. a Microbial crusts (black arrow) and foraminifers (white arrow) encrusting a Calcisponge (Sp); the framework is strengthened by early cements (EC). b Calcisponge (Sp) overgrown by microbial crusts (fine wrinkled laminations, black arrow). The microfacies shows abundant early cements (EC). c Autochthonous micrite (AM) with clotted peloidal fabric engulfing benthic microforaminifers. d Microtubus communis (Mi) and Tubiphytes sp. (T) veneered by

early cements (EC). Secondary cements (LC) fill the residual voids of the primary framework pores. e Baccanella floriformis (Bf) and autochthonous micrite (AM). f Framework pore, surrounded by early cement (EC), filled with allochthonous micrite (DM) and sparry calcite (LC). These geopetal structures developed in the fenestral pore of the microbialitic boundstones. a, b Sample LC38; c, e sample LC39; f sample LC 37 

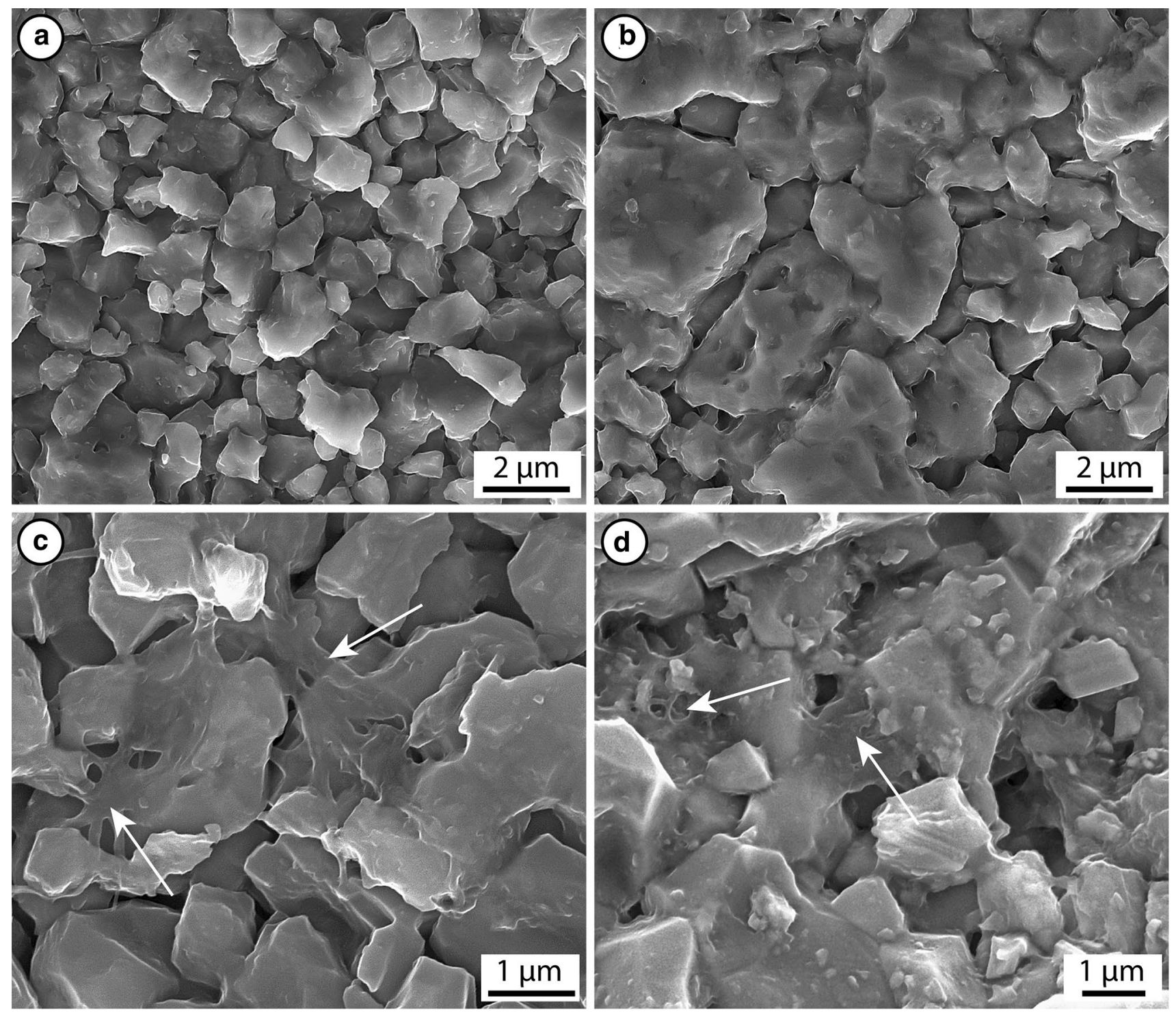

Fig. 7 SEM images of autochthonous (a) and allochthonous (b) micrites. Autochthonous micrite is composed of calcite crystals with sub-euhedral to anhedral morphologies, that show similar size (a) comparing to anhedral calcite crystals of the allochthonbous micrite (b), which have size in a wider range. c, $\mathbf{d}$ Amorphous carbonaceous

material (white arrows) among the fine crystals of autochthonous micrite, visible on etched surfaces of a thin section (c) and surface of a freshly broken rock fragment, not treated with acids (d). a, c, d Sample LC25; b sample LC1

fragments and detrital intervals. Clotted peloidal and aphanitic (structureless) textures are also widespread. Several generations of isopachous cements are present. They have a cloudy aspect, due to the presence of organic matter. Skeletal fragments of echinoderms and mollusks are less abundant. Homogeneous matrix containing small bioclasts and lithoclasts is encountered as detrital micrite. The amount and the relative texture of these components are variable in the different carbonate Units. Generally, the carbonates are affected by diagenesis, which sometimes make difficult to interpret the original microfacies.

\section{Micrite types}

The micrite is encountered mainly as microsparite as a consequence of the recrystallization processes which affected by the studied carbonates. Despite the diagenetic alteration, it was still possible to recognize two micrite types (Fig. 5a-d). They were discriminated by means of their depositional fabrics. Micrite organized in wrinkled laminations (Fig. 6a, b), pelodail clots (Fig. 6c), and structureless (aphanitic) (Fig. 5c), was attributed to autochthonous micrite derived from microbial metabolic activities. Micrite 

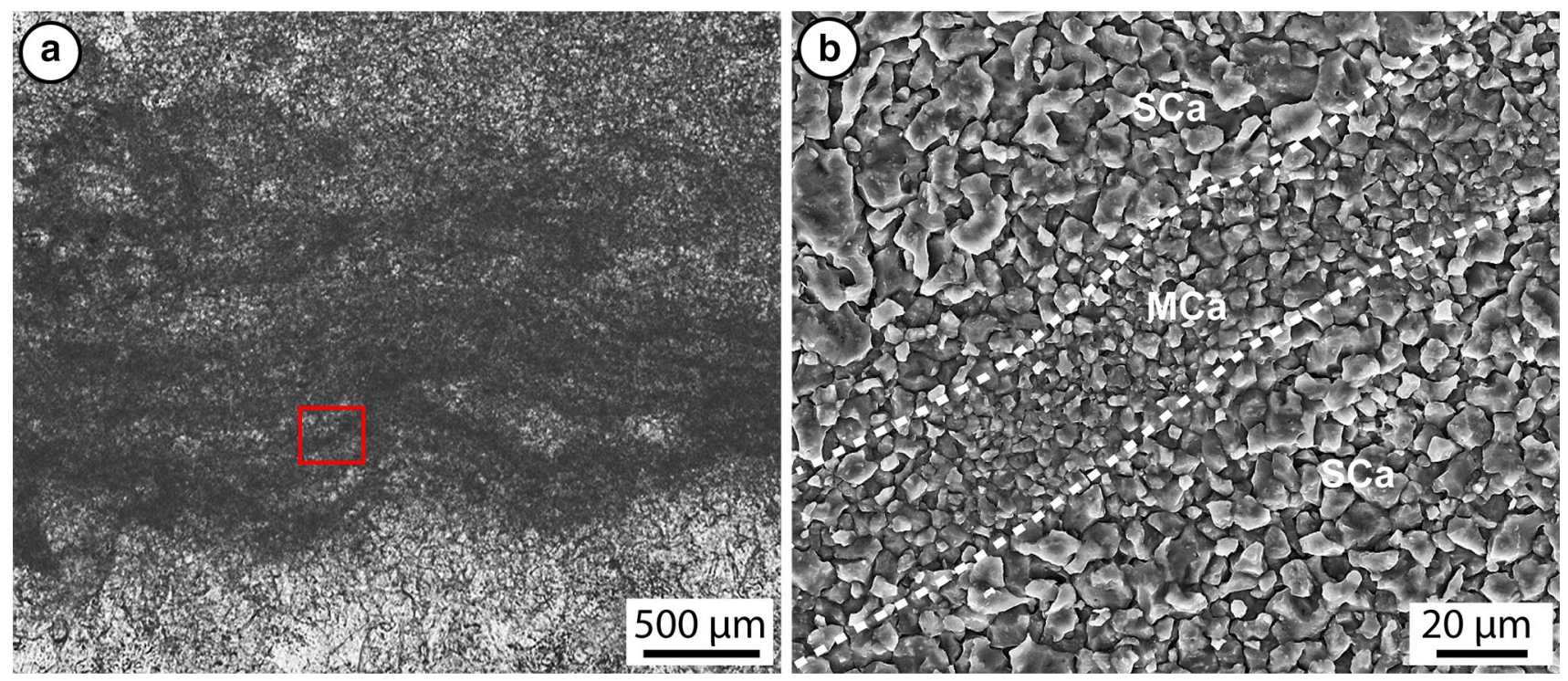

Fig. 8 Differences in crystal size between light and dark laminae showing a microbialite texture (a); the latter are composed of microcrystalline calcite $(<5 \mu \mathrm{m}, \mathrm{MCa})$, the former of microspar calcite $(>10 \mu \mathrm{m}, \mathrm{SCa})(\mathbf{b})$. Sample LC25

showing homogeneous and compact texture, which include fine bioclasts and lithoclasts, was attributed to allochthonous micrite. Autochthonous micrite, with finely crystalline light and dark wavy-wrinkled laminations, forms crusts that developed on various substrates (skeletal grains, intraclasts) (Fig. 6a, b). The growth patterns of these irregular crusts do not reflect physical depositional processes, notably transport and deposition. They are related to biological origin (microbial-mediated deposition) and syndepositional cementation (Fig. 5a, b). The bright epifluorescence of the autochthonous micrite suggests organic matter trapped among the finely calcite crystals (Fig. 5b, d). The presence of amorphous carbonaceous material among the fine crystals of autochthonous micrite, confirms the presence of organic matter and the bio-induced nature of this component. Organic matter remains were observed on both etched thin section surfaces and freshly broken fragments, do not treated with acids, excluding an artifact nature for their origin (Fig. 7a, c, d). Laminations occasionally form micro-columnar structures (Figs. 5a and 6b). Dark and light laminae differ in crystals size; the former are made of microcrystalline calcite $(<5 \mu \mathrm{m})$, the latter of microsparry calcite $(>10 \mu \mathrm{m})$ (Fig. 8). EPMA microanalysis revealed that the dark laminae are composed of low $\mathrm{Mg}$-calcite, with average $\mathrm{Ca}$ and $\mathrm{Mg}$ contents of 99 and $1 \mathrm{wt} \%$, respectively, whereas the light laminae show low $\mathrm{Mg}$-calcite with average $\mathrm{Ca}$ and $\mathrm{Mg}$ content of 98 and $2 \mathrm{wt} \%$, respectively.

Clotted peloidal micrite is often associated with calcimicrobes (Fig. 9a, b), microproblematica (Tubiphytes sp., Baccanella floriformis and Microtubus communis) (Fig. 9c-e), sponges (Olangocoelia otti) (Fig. 9f) and agglutinated polychaeta (Terebella) (Fig. 10c). The organic matter remains, revealed by UV epifluorescence, testify the bio-induced nature of this type of micrite. It is composed of low $\mathrm{Mg}$ calcite, showing a crystal size $<2 \mu \mathrm{m}$, with average $\mathrm{Ca}$ and $\mathrm{Mg}$ contents of 98.6 and $1.4 \mathrm{wt} \%$, respectively. Occasional autochthonous aphanitic micrite, often associated with $\mathrm{Bac}$ canella floriformis, is composed of low Mg-calcite, similar in composition to the peloidal micrite.

The allochthonous micrite has a homogeneous texture (Fig. 7b) and low content of organic matter, as indicated by the weak epifluorescence. Siliciclastic grains and clay minerals are dispersed within the bioturbated allochthonous micrite. This micrite type is abundant in Unit IIIa and II, and less frequent in Unit IIIb and Unit I.

\section{Microfacies of the carbonate units}

Unit IIla Detrital carbonates dominate Unit IIIa. Allochthonous micrite is abundant and the texture varies from mud (wackestones, Fig. 10a, b) to grain supported (packstones, Fig. 10c). Rare boundstones are present as cyanobacterial crusts, stabilizing medium-fine debris fractions (Fig. 10d). Lithoclasts, which are the main granular components (Fig. 10b), most likely originated as reworked boundstone, and are mainly composed of microproblematica (Tubiphytes sp., Baccanella floriformis), calcimicrobes (Girvanella sp.), and automicrite. The densely packed allochthonous micrite matrix shows mottles of bioturbation, engulfs small bioclasts and intraclasts (Fig. 10a), and is rich in green algae 

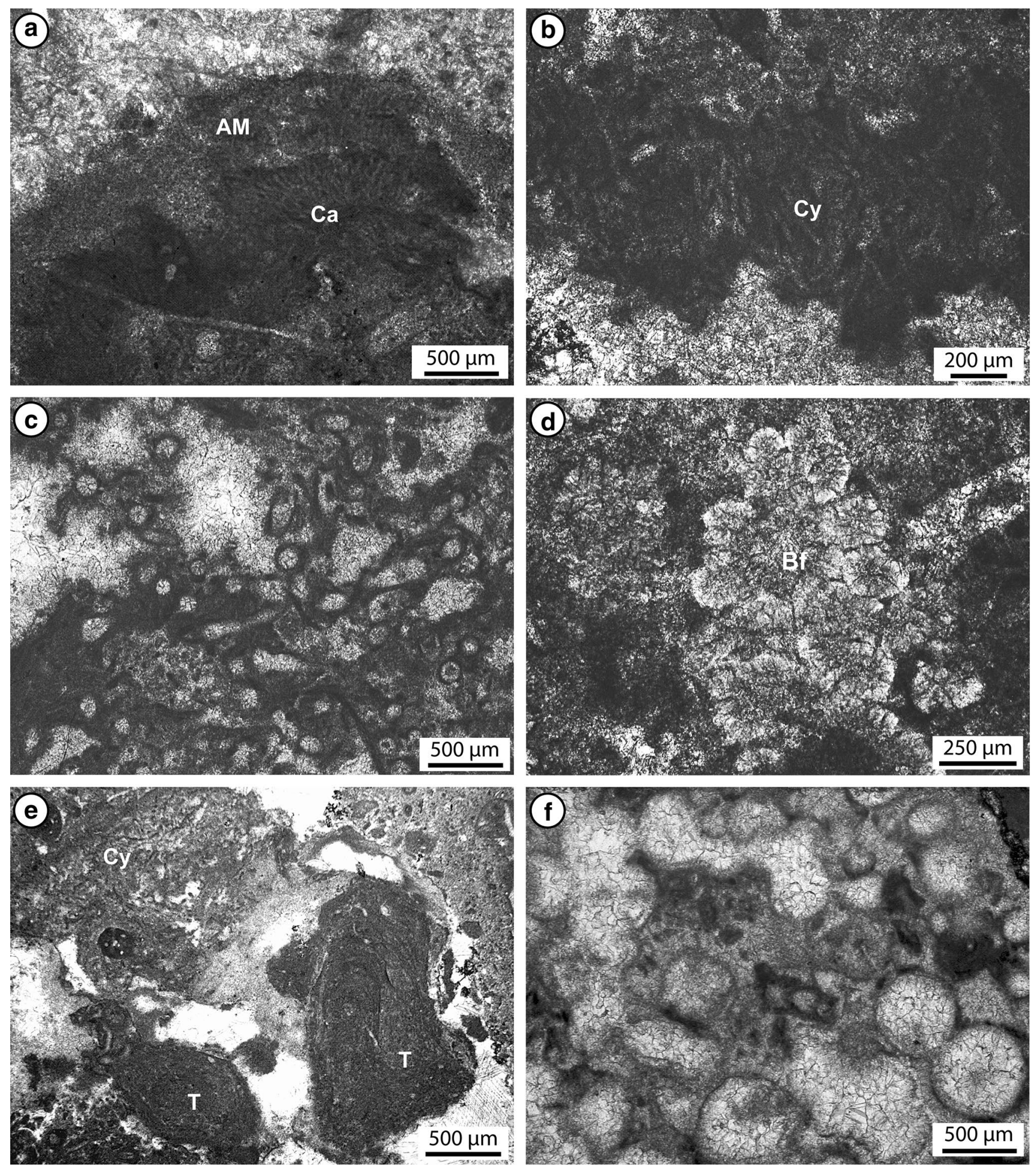

Fig. 9 Main components of the boundstone facies. a Autochthonous micrite with calcimicrobres; b calcified filamentous biofilms of cyanobacteria (Cy); c Microtubus communis; d Baccanella flo-

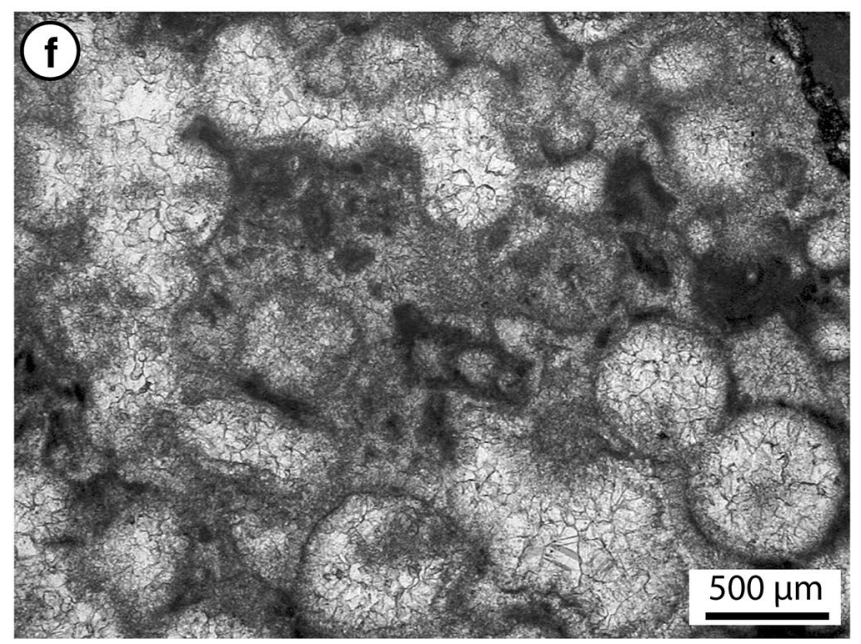

riformis (Bf); e Tubiphytes sp. (T); f Olangocoelia otti. a Sample LC27; b, d sample LC25; c sample LC39; e, f sample LC38 

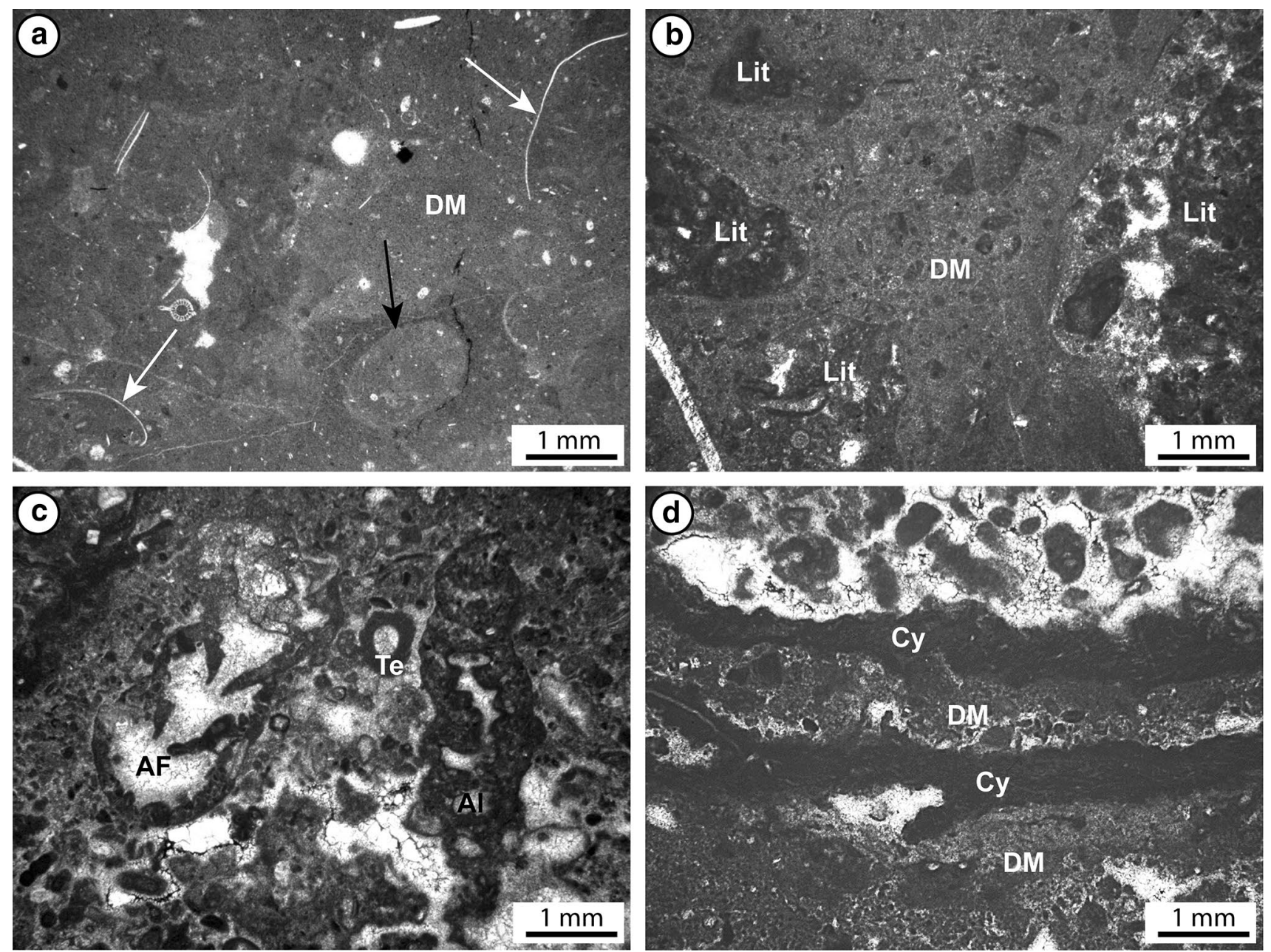

Fig. 10 a-c Detrital facies of Unit IIIa dominated by allochthonous micrite (DM), lithoclasts (Lit), skeletal fragments of thin-shelled bivalves (white arrows), calcareous algae (Al), agglutinated foraminifers (AF), and terebellids (Te). The allochthonous micrite shows bio-

turbation mottles (black arrow). d The few bindstone facies of Unit IIIa are present as cyanobacterial crusts (Cy), that stabilize allochthonous micrite (DM). a Sample LC2; b sample LC15; c, $\mathbf{d}$ sample LC 4

(Teutloporella herculea, Teutloporella nodosa), agglutinated foraminifers (Fig. 10c), and fragments of thin-shelled bivalves (Fig. 10a).

Unit IIlb The Unit IIIb shows a great abundance of autochthonous micrite (Fig. 11a-d), microproblematica (Fig. 11a), and cyanobacterial crusts (Fig. 11c). The micrite shows mainly peloidal to clotted peloidal textures (Fig. 11d). Aphanitic texture (Fig. 11a, b) and laminae with antigravitative structures (Fig. 11c) are also present. The Unit is dominated by boundstones carbonates, and the main skeletal components are represented by microproblematica (Tubiphytes sp., Baccanella floriformis and Microtubus communis) and calcimicrobes (i.e., Girvanella) (Fig. 11a-d). Autochthonous micrite with columnar micromorphology are common (Fig. 11c). Isopachous early cements, up to several millimeters in thickness, and

late druse cement, filling residual microcavities, are also present (Fig. 11b).

Unit II Unit II is dominated by packstones (Fig. 12), similar in composition to those of Unit IIIa, and it is rich in grains derived from reworked boundstones (Fig. 12a-d). Sample LC33 is a mudstone/wackestone with traces of bioturbations and fine skeletal grains. Thin-shelled bivalves are frequently present, in association with occasional fragments of calcisponges (Olangocoelia otti), gastropods and polychaets (Fig. 12c). Only one sample (LC32) shows abundant clasts of reworked boundstone rich in autochthonous micrite, microproblematica and cyanobacterial crusts, similar to those in Unit IIIb (Fig. 12b).

Unit I Unit I is mainly characterized by boundstones and rare packstones (Fig. 6a-f). The high amount of autoch- 

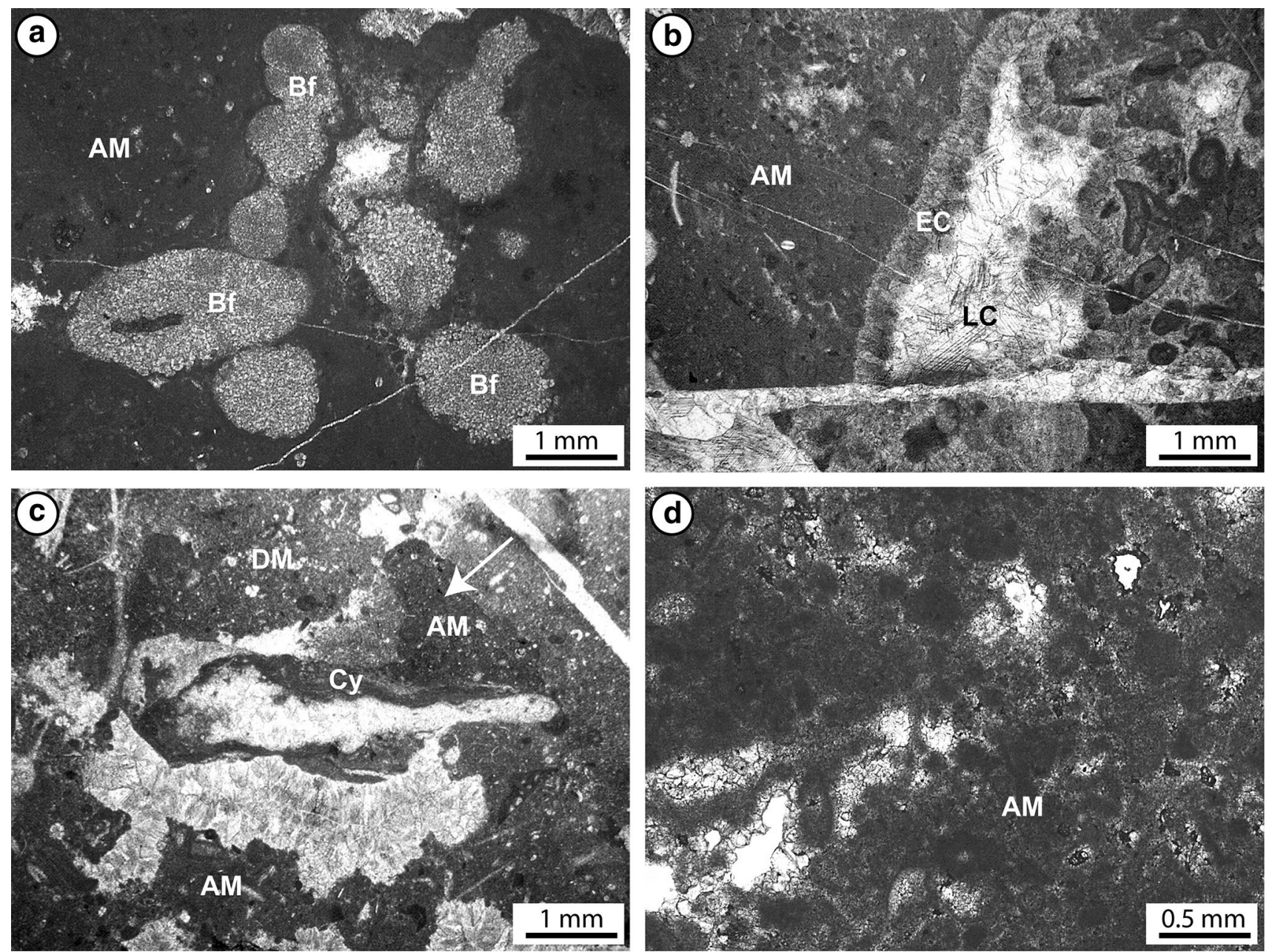

Fig. 11 a-d Boundstones facies of Unit IIIb with abundant autochthonous micrite (AM), cyanobacteria $(\mathrm{Cy})$, and microproblematica (Baccanella floriformis, Bf). Locally, early (EC) and late cements (LC) are present (b). Autochthonous micrite shows micro-columnar

structures (white arrow in c) and clotted micrite fabric (d). Scarce allochthonous micrite (DM) is trapped in microcavities of the boundstone framework. a-c Sample LC25; d sample LC29

thonous micrite shows peloidal to clotted peloidal texture (Fig. 6e). The main boundstone constituents are microproblematica (Baccanella floriformis, Microtubus communis and Tubiphytes sp.), calcisponges (Olangocoelia otti), and calcimicrobes (Girvanella) (Fig. 6a-d). Subordinate skeletons include dasycladacean algae (Diplopora annulata, Teutloporella herculea, Teutloporella nodosa) and agglutinated polychaets (Terebella). Inter-skeletal cavities are lined by isopachous polyphase millimeter- to centimeter-thick cements (Fig. 6f) that have a cloudy aspect due to the presence of organic matter, evidenced by UV epifluorescence observations (Fig. 5e, f).

Geopetal allochthonous micrite and sparry calcite fill microcavities of the microbial boundstones (Fig. 6f). They prove the in situ deposition of these microfacies and reveal the original growth polarity of the buildup, in agreement with the eastward younging direction indicated by field evidence.

\section{Early cements}

Early cements, mainly associated with autochthonous micrite, cyanobacterial crusts and microproblematica, had a significant role in stabilizing the boundstones. They occur in Unit IIIb (Fig. 7b) and appear abundant in Unit I (Fig. 6f). These cements were observed in polished hand specimens as fibrous calcite bands of various thickness (from millimeter to centimeter) and appearance (cloudy and whitish). Cements occlude the primary porosity of the microbialite/microproblematica framework. Lithoclasts of reworked boundstone sometimes provided the substrate for the growth of the isopachous cements. These cements are characterized by alternation of cloudy and whitish bands showing epifluorescence, indicating that the organic matter is mainly concentrated in the cloudy bands (Fig. 5e, f). 

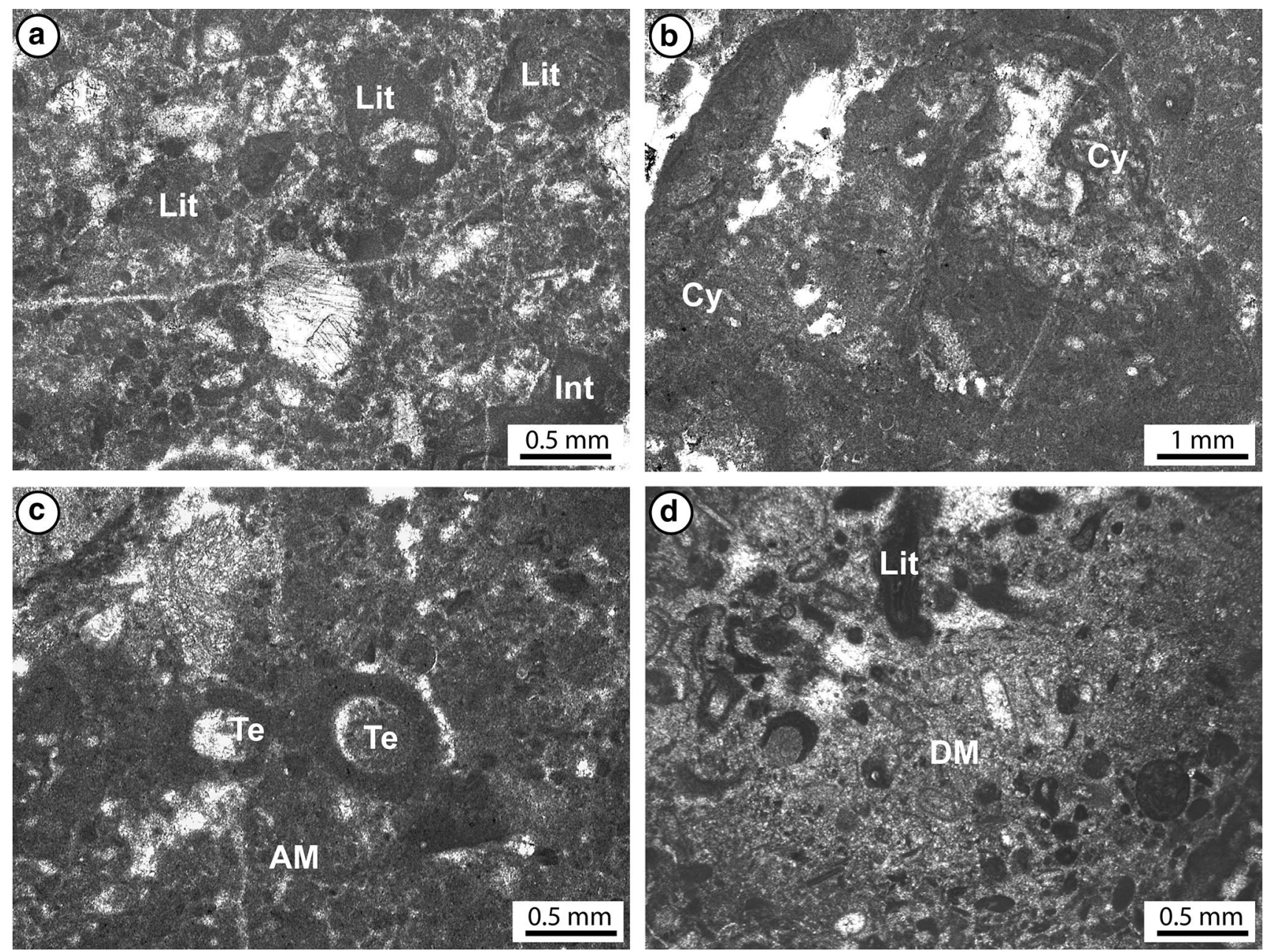

Fig. 12 a-d Detrital facies of Unit II are characterized by abundant allochthonous micrite (DM). The most common facies is packstone rich in grains of reworked boundstone fragments (Lit). The main car-

bonate fragments are from terebellid skeletons (Te) and cyanobacterial crusts (Cy). Autochthonous micrite (AM in c) is rare. a, d Sample LC31; b, c sample LC32

\section{Quantitative analyses of the microfacies}

Quantitative analyses of the carbonate components were performed by point counting (Table 1 and 2). The microfacies were grouped into: (1) autochthonous carbonates, mainly formed of cyanobacterial crusts, microproblematica, microbial micrite, and boundstone sponges; (2) detrital carbonates, formed of bioclasts, intraclasts, lithoclasts, and allochthonous micrite. Isopachous (early) and drusy (late) cements were counted separately, both showing a weak and barely significant increase moving up-section.

The data show a general increase, from Unit III to Unit I, in autochthonous relative to detrital carbonates components (Fig. 13).

In the autochthonous carbonates (Units IIIb and I), with typical boundstone facies, the peloidal micrite (40-63\%) is the main constituent among bio-induced autochthonous micrite, followed by laminated microfabrics (1-4\%), and

aphanitic micrite $(0.5-2 \%)$. Cyanobacterial crusts are present throughout the succession, constituting from 2 to $8 \%$ of the total microfacies of the autochthonous carbonates. Similarly, microproblematica constitutes from 1 to $6 \%$ of the total rock volume.

Utilizing the sample positions as independent variable and the quantitative amount of autochthonous carbonates as dependent variable, it is possible to recognize a discrete positive linear regression $(y=0.002 x+0.129)$ with a correlation coefficient $R^{2}=0.60$ (Fig. 14a). This is consistent with a linear increase of the autochthons carbonate toward the top of the succession. The sample positions vs detrital carbonates shows a negative linear regression $(y=-0.0026 x+0.8124)\left(R^{2}=0.66\right)$, confirming a linear decrease of detrital carbonates toward the top of the succession (Fig. 14b). If we assume that Unit II was positioned at the base of the sequence before the tectonic events, the coefficients $R^{2}$ increase considerably ( 0.75 and 
Table 1 Quantitative data (the values are expressed in \%) on the constituents in the four carbonate units

\begin{tabular}{|c|c|c|c|c|c|c|c|c|c|c|c|c|}
\hline & \multirow[t]{3}{*}{ Sample } & \multicolumn{6}{|c|}{ Autochthonous carbonates } & \multicolumn{3}{|c|}{ Detrital carbonates } & \multicolumn{2}{|c|}{ Cements } \\
\hline & & \multicolumn{3}{|l|}{ Microbialites } & \multirow{2}{*}{$\begin{array}{l}\text { Micro- } \\
\text { problem- } \\
\text { atica }\end{array}$} & \multirow{2}{*}{$\begin{array}{l}\text { Cyano- } \\
\text { bacterial } \\
\text { crusts }\end{array}$} & \multirow[t]{2}{*}{ Sponge } & \multirow{2}{*}{$\begin{array}{l}\text { Alloch- } \\
\text { thonous } \\
\text { micrite }\end{array}$} & \multirow{2}{*}{$\begin{array}{l}\text { Intra- } \\
\text { clasts/ } \\
\text { lithoclasts }\end{array}$} & \multirow[t]{2}{*}{ Bioclasts } & \multirow[t]{2}{*}{ Early } & \multirow[t]{2}{*}{ Late } \\
\hline & & Clotted micrite & $\begin{array}{l}\text { Struc- } \\
\text { tureless } \\
\text { micrite }\end{array}$ & $\begin{array}{l}\text { Lami- } \\
\text { nated } \\
\text { micrite }\end{array}$ & & & & & & & & \\
\hline \multirow[t]{4}{*}{ Unit I } & LC41 & 62.75 & 1.00 & 2.00 & 1.00 & 4.50 & - & 2.00 & 1.00 & 1.75 & 20.50 & 3.50 \\
\hline & LC40 & 46.00 & 1.00 & 1.50 & 6.50 & 6.00 & 2.00 & 19.50 & 0.50 & 4.25 & 3.50 & 9.25 \\
\hline & LC38 & 57.75 & 1.50 & 1.50 & 1.00 & 2.00 & 0.25 & 1.75 & - & 3.25 & 26.50 & 4.50 \\
\hline & LC36 & 46.50 & 0.75 & 3.00 & 1.25 & 6.00 & - & 3.75 & - & 5.50 & 22.25 & 11.00 \\
\hline Unit II & LC31 & 4.75 & 1.50 & - & 2.50 & 3.75 & 1.50 & 48.00 & 0.50 & 18.50 & 7.75 & 11.25 \\
\hline \multirow[t]{5}{*}{ Unit IIIb } & LC30 & 41.25 & 0.50 & 2.25 & 3.00 & 5.50 & - & 7.00 & 8.50 & 17.00 & 9.25 & 5.75 \\
\hline & LC29 & 61.75 & 0.25 & 1.25 & 1.25 & 5.25 & - & 3.50 & 3.50 & 17.75 & 2.00 & 3.50 \\
\hline & $\mathrm{LC} 27$ & 47.25 & 2.00 & 4.25 & 1.75 & 8.25 & - & - & - & 14.75 & 19.25 & 2.50 \\
\hline & LC24 & 40.00 & 1.00 & 2.75 & 4.00 & 5.00 & - & 19.00 & - & 14.00 & 9.75 & 4.50 \\
\hline & $\mathrm{LC} 24$ & 42.00 & 0.75 & 3.25 & 2.25 & 5.75 & - & 8.00 & 9.25 & 13.75 & 9.00 & 6.00 \\
\hline \multirow[t]{10}{*}{ Unit IIIa } & LC19 & 2.75 & 0.50 & - & 3.00 & 5.00 & - & 65.00 & 9.00 & 8.25 & - & 6.50 \\
\hline & LC17 & - & 1.25 & - & 1.25 & 11.25 & 1.75 & 61.00 & 5.75 & 8.75 & 3.50 & 5.50 \\
\hline & LC15 & 29.25 & - & - & - & 2.50 & - & 51.75 & 5.50 & 6.50 & - & 4.50 \\
\hline & LC13 & 3.25 & 0.50 & 17.00 & - & 4.50 & 9.75 & 48.50 & - & 3.25 & 11.25 & 2.00 \\
\hline & LC12 & 7.75 & 0.50 & - & 2.00 & 6.50 & - & 62.75 & 6.25 & 9.75 & - & 4.50 \\
\hline & LC8 & - & 1.25 & - & - & 4.75 & - & 71.75 & 5.25 & 11.50 & - & 5.50 \\
\hline & LC6 & - & - & - & - & 3.25 & - & 76.50 & 6.25 & 10.50 & - & 3.50 \\
\hline & $\mathrm{LC} 4$ & - & 0.50 & - & - & 14.00 & 2.25 & 71.25 & 2.50 & 5.25 & - & 4.25 \\
\hline & $\mathrm{LC} 2$ & 3.50 & 1.25 & - & 6.75 & 4.75 & 1.00 & 56.50 & 8.75 & 7.25 & 4.50 & 5.75 \\
\hline & LC1 & 3.00 & 1.00 & - & 3.00 & 13.50 & 5.50 & 47.00 & 1.75 & 6.50 & 15.50 & 3.25 \\
\hline
\end{tabular}

The constituents were grouped into three classes: autochthonous carbonates components, detrital carbonates components and cements, in turn subdivided into early and late cements

0.74, respectively) (Fig. 14c, d), strengthening the hypothesis of the unit displacement after its origination.

\section{Interpretation and discussion}

\section{Microfacies evolution and paleoenvironmental reconstruction}

The well-preserved carbonate bodies of the "La Cerchiara" succession allow us to propose a model for the paleoenvironment reconstruction of a Middle Triassic buildup of Southern Apennines (Italy). We suggest that the quantitative variations in microfacies, depositional textures, cement abundances and micrites type, indicate a depositional evolution from lower to upper slope facies. The wackestones and packstones of Unit IIIa, originally consisting of loose detrital sediments, correspond to distalslope facies, supplied by a bio-constructed margin located, probably, to the east of the study area (Fig. 15). The few boundstone horizons are formed by fine detrital grains, encrusted and stabilized by microbial laminae, forming bindstone fabric.

Unit IIIb and Unit I represent the upper slope/margin of the buildup, deposited into a shallower environment. This is suggested by the increase in boundstones, rich in autochthonous micrite, cyanobacterial crusts, microproblematica and early cements.

Ciarapica and Passeri (2000), considering their paleontological content, interpreted the two carbonate units of Unit IIIa and Unit IIIb as coeval parts of the same carbonate body, superposed one upon each other by a tectonic contact. Our microfacies data suggest that these carbonate bodies record different depositional environments. Specifically, Unit IIIa was deposited on a distal slope and Unit IIIb in an upper slope environment. Unit I represents the marginal extension of the bioconstruction (Fig. 15). The thin Unit II, cropping out between Unit IIIb and I, records a sharp change in depositional facies, from upper slope autochthonous micrite to allochthonous/detrital micrite of the distal-slope basin (Fig. 15). This abrupt change can be explained either by tectonic displacement of the thin Unit II, from the base 
Table 2 Quantitative data averages of the main constituents in the carbonate Units

\begin{tabular}{|c|c|c|c|c|c|c|c|c|c|}
\hline & \multirow[t]{2}{*}{ Sample } & \multicolumn{2}{|c|}{$\begin{array}{l}\text { Autochthonous } \\
\text { carbonates }\end{array}$} & \multicolumn{2}{|c|}{ Detrital carbonates } & \multicolumn{2}{|c|}{ Early cements } & \multicolumn{2}{|c|}{ Late cements } \\
\hline & & Value & Average & Value & Average & Value & Average & Value & Average \\
\hline \multirow[t]{4}{*}{ Unit I } & LC41 & 71.25 & \multirow[t]{4}{*}{63.94} & 4.75 & 10.81 & 20.50 & \multirow[t]{4}{*}{18.19} & 3.50 & \multirow[t]{4}{*}{7.06} \\
\hline & LC40 & 63.00 & & 24.25 & & 3.50 & & 9.25 & \\
\hline & LC38 & 64.00 & & 5.00 & & 26.50 & & 4.50 & \\
\hline & LC36 & 57.50 & & 9.25 & & 22.25 & & 11.00 & \\
\hline Unit II & LC31 & 14.00 & 14.00 & 67.00 & 67.00 & 7.75 & 7.75 & 11.25 & 11.25 \\
\hline \multirow[t]{5}{*}{ Unit IIIb } & LC30 & 52.50 & \multirow[t]{5}{*}{58.50} & 32.50 & 27.20 & 9.25 & \multirow[t]{5}{*}{9.85} & 5.75 & \multirow[t]{5}{*}{4.45} \\
\hline & LC29 & 69.75 & & 24.75 & & 2.00 & & 3.50 & \\
\hline & $\mathrm{LC} 27$ & 63.50 & & 14.75 & & 19.25 & & 2.50 & \\
\hline & $\mathrm{LC} 24$ & 52.75 & & 33.00 & & 9.75 & & 4.50 & \\
\hline & LC23 & 54.00 & & 31.00 & & 9.00 & & 6.00 & \\
\hline \multirow[t]{10}{*}{ Unit IIIa } & LC19 & 11.25 & \multirow[t]{10}{*}{17.95} & 82.25 & 74.05 & - & \multirow[t]{10}{*}{3.48} & 6.50 & \multirow[t]{10}{*}{4.53} \\
\hline & $\mathrm{LC} 17$ & 15.50 & & 75.50 & & 3.50 & & 5.50 & \\
\hline & LC15 & 31.75 & & 63.75 & & - & & 4.50 & \\
\hline & LC13 & 35.00 & & 51.75 & & 11.25 & & 2.00 & \\
\hline & LC12 & 16.75 & & 78.75 & & - & & 4.50 & \\
\hline & LC8 & 6.00 & & 88.50 & & - & & 5.50 & \\
\hline & LC6 & 3.25 & & 93.25 & & - & & 3.50 & \\
\hline & LC4 & 16.75 & & 79.00 & & - & & 4.25 & \\
\hline & $\mathrm{LC} 2$ & 17.25 & & 72.50 & & 4.50 & & 5.75 & \\
\hline & LC1 & 26.00 & & 55.25 & & 15.50 & & 3.25 & \\
\hline
\end{tabular}

of the succession to its current position between the Unit IIIB and I, or by an abrupt variation in paleoenvironmental conditions. The correlation coefficients $R^{2}$ ( 0.60 for autochthonous carbonate and 0.66 for detrital carbonates) increase moving the Unit II at the base of the succession ( 0.75 for autochthonous carbonate and 0.76 for detrital carbonates). These data strengthen the hypostasis of a tectonic displacement of Unit II.

Thus, the quantitative microfacies analysis indicates the development of a single carbonate system, in which the facies pass eastward from a distal slope to a proximal margin facies. In our interpretation, the carbonate units at "La Cerchiara" derive from a unitary buildup succession. This is in agreement with the models proposed by Miconnet (1988) and Palladino et al. (2019), in which the Monte Facito Formation would consist of different part of a series of platform units, partly re-sedimented into siliciclastic basinal sediments of Ladinian age and later disrupted by tectonic deformation.

\section{Depositional relationships between the carbonate units}

The basal and lateral relations of the carbonate bodies are not visible. In addition, while the western part of the outcrop (Unit IIIa) is organized in more or less planar beds, the eastern part (Unit IIIb and Unit I) has a massive appearance, with variable lateral thickness. However, the variations in the carbonate constituents, revealed by the quantitative microfacies analyses, reflect the primary depositional relationships. The lower beds (Unit IIIa) are mainly characterized by detrital microfacies, while the upper massive bodies (Unit IIIb and Unit I) mainly consist of syndepositional cemented autochthonous boundstones. Micrite type varies along the section: allochthonous micrite prevails in the lower interval and tends to decrease in abundance towards the upper interval, where it is progressively substituted by autochthonous micrite. The variation from allochthonous to autochthonous micrite and the sindepositional cementation of the boundstone facies could reflect a change in the growth morphology of the buildup, even though this is presently obscured by the tectonic deformation. A similar trend occurs in an upper Anisian platform of the Dolomites (Sasso Bianco section, Formazione di Contrin) (Guido et al. 2016). Here, the succession records a change from loose detrital micrite, which dominates the lower carbonate bank, to syndepositional lithified micrite in the upper buildup (Guido et al. 2016). This variation is associated to a change in the depositional geometry, i.e. the steepening up of the slope. Similar relationships between carbonate sediments and depositional slope geometries have been documented by numerous studies (Kirkby 1987; Kenter 1990; Adams et al. 1998, 2002; 


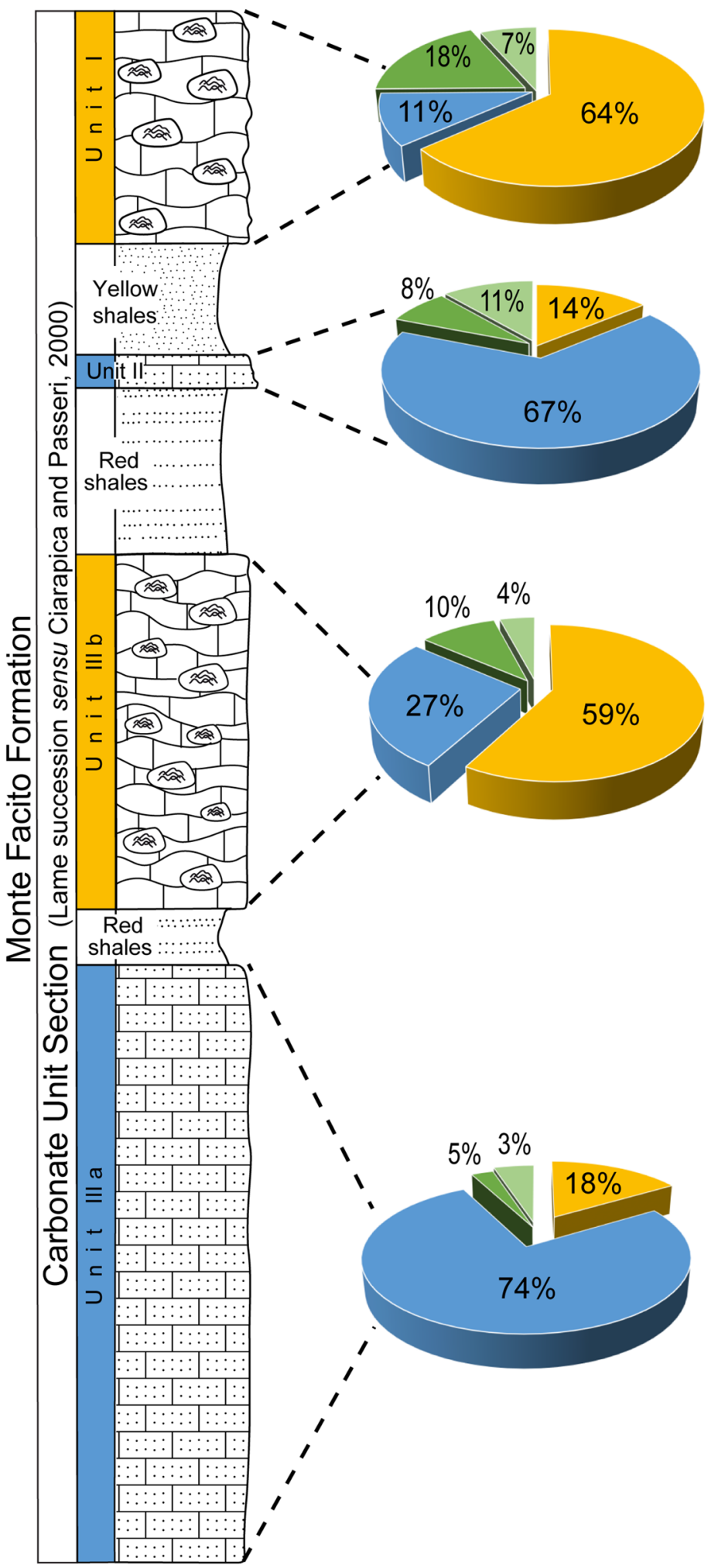

Late cements

Early cements

Autochthonous carbonates

Detrital carbonates

Fig. 13 Percentage of the main microfacies constituents in the carbonate units. The planar beds of the Unit IIIa and Unit II are mainly detrital facies, whereas the poorly defined massive layers of Unit IIIb and Unit I are composed mainly of autochthonous carbonates rich in microbialites 

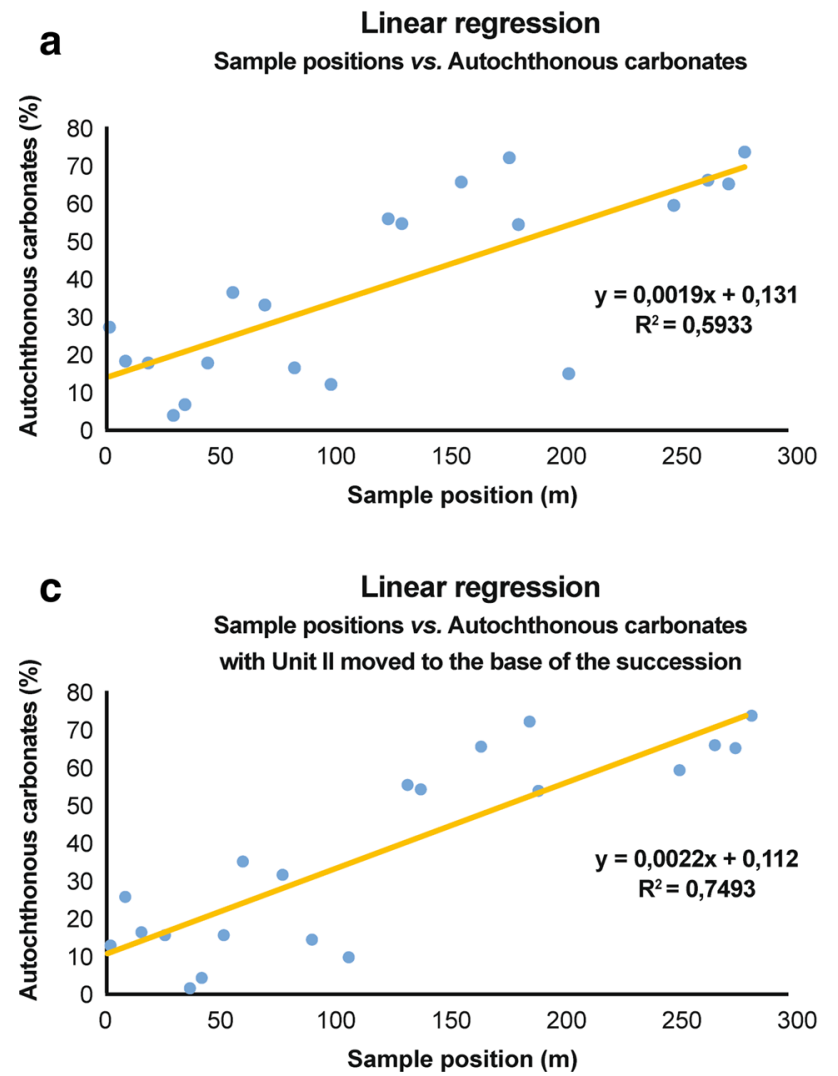

Fig. 14 a Linear regression of the sample positions vs autochthonous carbonates. b Linear regression of the sample position vs detrital carbonate. $\mathbf{c}$ Linear regression of the sample positions vs autochthonous carbonates with Unit II moved to the base of the succession. $\mathbf{d}$ Linear regression of the sample position vs detrital carbonate with Unit II moved to the base of the succession. The statistic evaluation of the

Keim and Schlager 1999; Adams and Schlager 2000; Marangon et al. 2011). Schlager and Reijmer (2009) showed how different types of micrite affect the depositional geometry of slopes. Loose sedimentary particles precipitate as mud can readily be re-suspended during storms and exported to form low-angle slopes. On the contrary, in situ precipitation induced by microbial activity can form autochthonous early cemented micrite that stabilizes sediment on steep slopes.

\section{Comparison with coeval Anisian-Ladinian carbonate buildups}

The absence of metazoan reefal communities, forming a primary skeletal framework, and the dominance of microencrusters, microbialites and synsedimentary cements, are characteristics of early-middle Anisian period in the western Tethyan buildups of the Dolomites (Bosellini and Rossi 1974; Cros 1974; Gaetani et al. 1981; Bosellini 1984; Fois and Gaetani 1984; Gaetani and Gorza 1989; Brandner et al. 1991, 2012; Senowbari-Daryan et al. 1993; Blendinger 1994; Harris 1994, 1996; Russo et al. 1997, 2000; Keim
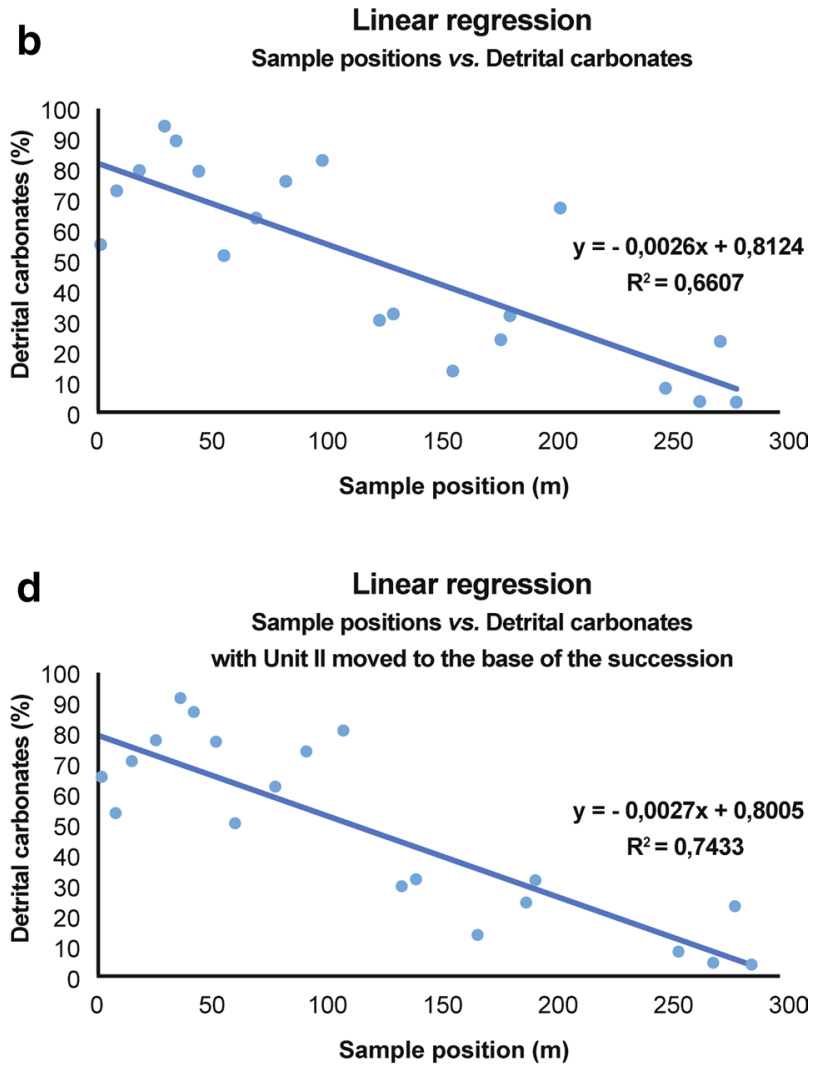

quantitative data shows a linear increase tendency of the autochthonous carbonates and a linear decrease of the detrital carbonates towards the top of the succession. These linear regressions are more consistent moving the Unit II at the base of the succession as revealed by the increase of $R^{2}$ coefficients

and Schlager 1999, 2001; Emmerich et al. 2005; Russo 2005; Schlager and Keim 2009; Stefani et al. 2010; Marangon et al. 2011; Tosti et al. 2011, 2012, 2014; Guido et al. 2016, 2019). Synsedimentary autochthonous micrite, Tubiphytes and cement crusts have also been recorded in middle Anisian buildups of the northern and western Tethys (Okay et al. 1994; Grădinaru 1995, 2000; Săndulescu 1995; Banks and Robinson 1997; Török 1998; Szulc 2002; Hips 2007; Popa et al. 2014; Hips et al. 2015; Martindale et al. 2019). Similar evolution, from lower to upper slope facies, was also detected in Anisian platforms of the eastern Tethys (Enos et al. 1997, 2006; Kershaw et al. 1999, 2002, 2007, 2012; Lehrmann 1999; Payne et al. 2006, 2011; Lehrmann et al. 2007; Cao and Zheng 2009; Chen et al. 2009; Feng et al. 2010).

Fois and Gaetani (1984) described the recovery of rich and well-preserved Anisian reef-building communities in the Italian Dolomites. They recognized three growth stages of reefs, after the Permian-Triassic crisis. Although less rich and not so well preserved, the carbonate Units of the "La Cerchiara" succession are 


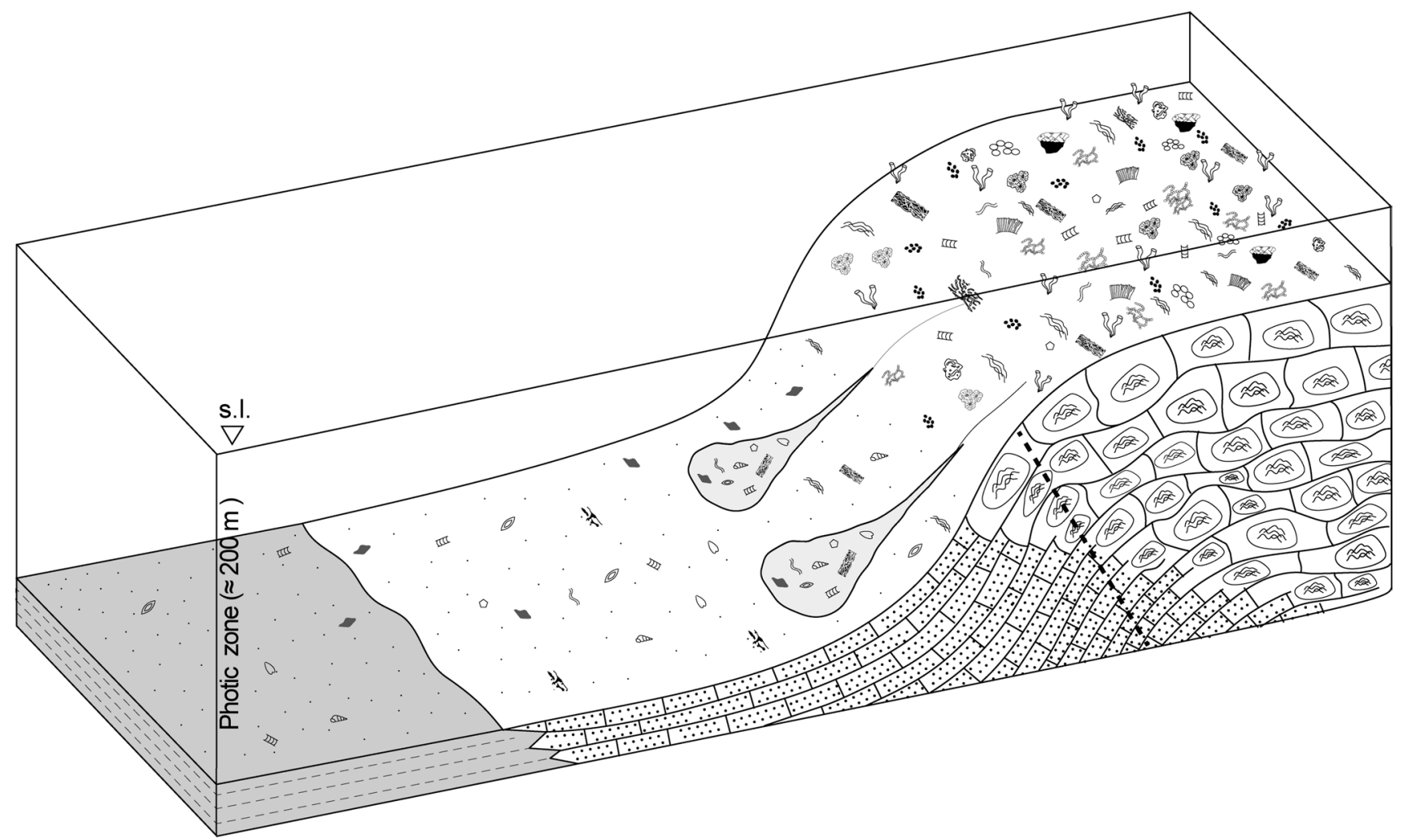

Benthic foramin
Encrusting foram
Sponges
Tubiphytes sp.
Echinodermata
Gastropods

Fig. 15 Reconstruction of the early-middle Anisian build-up. The facies interpretation suggest that the studied units belonged to a single carbonate system, partly disrupted by later tectonic deformation. The microfacies analyses indicate transition from distal-slope detrital

similar to the mounds described by Fois and Gaetani (1984). Nevertheless, it is clear that both communities lacked primary skeletal framework, although this was, to some extent, substituted by autochthonous micrite, encrusting algae, microproblematica and porifera. Some organisms are present in Anisian sediments of both both "La Cerchiara" and the Dolomite, e.g., calcareous algae (Diplopora annulata, Teutloporella herculea, Teutloporella nodosa, Physoporella sp.), Tubiphytes, Olangocoelia otti and cyanobacteria. The abundance of early cements in the "La Cerchiara" carbonates together with the minor abundance of organisms, represents a significant difference, in comparison with Anisian
Olangocoelia otti

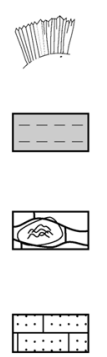

Isopachous cements

Shales

Baccanella floriformis

Autochthonous carbonates

Microtubus communis

Geopetal infilling

Bioturbation
Detrital carbonates facies, recorded in Units II and IIIa, to the upper slope/margin boundstone, recorded in Units IIIb and I. The dotted line represents the probable primary location of the studied section through the buildup

facies of the Dolomites described by Fois and Gaetani (1984). The studied units show similarity also with middle Anisian carbonates cropping out in south-eastern Romania (Popa et al. 2014), that consist of microbialitic boundstones, allochthonous micrite, and Tubiphytes, reinforced by large volumes of marine cements. The studied microfacies, of the central Mediterranean area, are comparable in term of amount of autochthonous micrite, with those of the Middle Triassic Hungarian reefs, but in these latter microbialites play a mutual role with sponges in formation of typical mud-mound deposit (Török 1998; Schlager 2003; Hips 2007; Hips et al. 2015; Martindale et al. 2019). 
The widespread presence of microbialites and the lack of skeletal framework suggests a "mud mound" growth model for the Anisian "La Cerchiara" buildup. Microbialites are known to have significantly contributed to "reef"-like structures, in the past as well as in the present (e.g. Wood 1999, 2001; Saint-Martin et al. 2000; Olivier et al. 2004; Nose et al. 2006; Westphal et al. 2010; Sánchez-Beristain and Reitner 2019) and their role in building "mud mound"-like structures has long been recognized (Reitner and Neuweiler 1995; Dupraz and Strasser 2002; Chan et al. 2014). They can reach significant abundances (more than 50\%) in ancient frameworks, particularly after major extinction events (Zhuravlev 1996; Turner et al. 2000; Shapiro 2004; Delecat and Reitner 2005; Ezaki et al. 2008; Zamagni et al. 2009; Tunis et al. 2011; Astibia et al. 2012; Kershaw et al. 2012; Wahlman et al. 2013; Kershaw 2017).

\section{Conclusion}

Before reworking, the carbonate units of the "La Cerchiara" succession belong to a single buildup, characterized by the absence of a skeletal framework, with high abundances of micro-encrusters, microbialites and early cements. The microfacies quantitative study of the carbonate units revealed a linear trend from detrital to autochthonous carbonate. The positive linear regression of the sample positions vs quantitative amount of autochthonous constituents moving toward the top of the succession, and the negative linear regression of sample positions vs detrital constituents in the same direction support this hypothesis.

The microfacies change is also in agreement with the inferred depositional geometries of the carbonate buildup. The change from the sub-horizontal beds of Unit IIIa to the massive beds of Units IIIb and I strengthens the model of a transition from distal-slope allochthonous sediments to upper slope/margin syndepositionally cemented and bio-constructed deposits. Statistical data suggest that units IIIa, IIIb and I are in stratigraphic order while unit II appears to have been moved by tectonic dislocation from its original position at the base of the succession. The richness in micro-encrusters, autochthonous micrite, and synsedimentary cements, together with the absence of metazoan reef communities forming a primary framework, suggests strong similarities with microbial-mound platform facies of similar early-middle Anisian age developed in the western Tethys.

Acknowledgements The authors wish to express their gratitude to Robert Riding for constructive comments and suggestions. Dr Mariano Davoli, University of Calabria, is thanked for help for technical support during SEM and EPMA data acquisition. This research was financially supported by MIUR (ex 60\% 2019 A. Guido, University of Calabria). Data available on request from the authors.
Funding Open access funding provided by Università della Calabria within the CRUI-CARE Agreement.

Open Access This article is licensed under a Creative Commons Attribution 4.0 International License, which permits use, sharing, adaptation, distribution and reproduction in any medium or format, as long as you give appropriate credit to the original author(s) and the source, provide a link to the Creative Commons licence, and indicate if changes were made. The images or other third party material in this article are included in the article's Creative Commons licence, unless indicated otherwise in a credit line to the material. If material is not included in the article's Creative Commons licence and your intended use is not permitted by statutory regulation or exceeds the permitted use, you will need to obtain permission directly from the copyright holder. To view a copy of this licence, visit http://creativecommons.org/licenses/by/4.0/.

\section{References}

Adams EW, Schlager W (2000) Basic types of submarine slope curvature. J Sediment Res 70:814-828

Adams EW, Schlager W, Wattel E (1998) Submarine slopes with an exponential curvature. Sediment Geol 117:135-141

Adams EW, Morsilli M, Schlager W, Keim L, Van Hoek T (2002) Quantifying the geometry and sediment fabric of linear slopes: examples from the Tertiary of Italy (Southern Alps and Gargano Promontory). Sediment Geol 154:11-30

Argnani A (2013) The role of Mesozoic palaeogeography in the evolution of the Southern Apennines. Rend Soc Geol Ital 25:11-20

Astibia H, López-Martínez N, Elorza J, Vicens E (2012) Increasing size and abundance of microbialites (oncoids) in connection with the $\mathrm{K} / \mathrm{T}$ boundary in non-marine environments in the South-Central Pyrenees. Geol Acta 10:209-226

Banks CJ, Robinson AG (1997) Mesozoic strike-slip back-arc basins of the Western Black Sea Region. In: Robinson AG (ed) Regional and petroleum geology of the Black Sea and surrounding region, vol 68. AAPG Memoir, pp 53-61

Baud A, Cirilli S, Marcoux J (1997) Biotic response to mass extinction: the lowermost Triassic microbialites. Facies 36:238-242

Baud A, Richoz S, Pruss S (2007) The lower Triassic anachronisitic carbonate facies in space and time. Global Planet Change 55:81-89

Bechstädt T, Brandner R (1970) Das Anis zwischen St. Vigil und dem Höhlensteintal (Pragser und Olanger Dolomiten, Südtirol). Festbd Geol Inst, 300-Jahr-Feier Universität Innsbruck, pp 9-103

Biddle KT (1981) The basinal Cipit boulders: indicators of Middle to Upper Triassic buildup margins, Dolomite Alps, Italy. Riv Ital Paleont Strat 86:779-794

Blendinger W (1994) The carbonate factory of Middle Triassic buildups in the Dolomites, Italy: a quantitative analysis. Sedimentology 41:1147-1159

Blendinger W (1996) The carbonate factory of Middle Triassic buildups in the Dolomites, Italy: a quantitative analysis (Reply). Sedimentology 43:402-404

Bosellini A (1984) Progradation geometries of carbonate platforms: examples from the Triassic of the Dolomites, Northern Italy. Sedimentology 31:1-24

Bosellini A, Rossi D (1974) Triassic carbonate buildups of the Dolomites, Northern Italy. In: Laporte LF (ed) Reefs in time and space: selected examples from the recent and ancient, vol 18. SEPM Special Publication, Tulsa, pp 209-233

Brandner R, Keim L (2011) A 4-day geological field trip in the Western Dolomites. Geo Alp 8:76-118 
Brandner R, Resch W (1981) Reef development in the Middle Triassic (Ladinian and Cordevolian) of the Northern Limestone Alps near Innsbruck Austria. In: Toomey DF (ed) European fossil reef models, vol 30. SEPM Special Publication, pp 203-231

Brandner R, Flügel E, Senowbari-Daryan B (1991) Microfacies of carbonate slope boulders: indicator of the source area (Middle Triassic: Mahlknecht Cliff, Western Dolomites). Facies 25:279-296

Brandner R, Gruber A, Keim L (2007) Geologie der westlichen Dolomiten: von der geburt der neotethys im perm zu karbonatplattformen, Becken, und Vukaniten der Triss. Geo Alp 4:95-121

Brandner R, Horacek M, Keim L (2012) Permian-Triassic-boundary and Lower Triassic in the Dolomites, Southern Alps (Italy). Mitt Ges Geol Bergbaustud Österr 54:379-404

Brayard A, Vennin E, Olivier N, Bylund KG, Jenks J, Stephen DA, Bucher H, Hofmann R, Goudemand N, Escarguel G (2011) Transient metazoan reefs in the aftermath of the end-Permian mass extinction. Nat Geosci 4:693-697

Bucci F, Novellino R, Tavarnelli E, Prosser G, Guzzetti F, Cardinali M, Gueguen E, Guglielmi P, Adurno I (2014) Frontal collapse during thrust propagation in mountain belts: a case study in the Lucania Apennines, Southern Italy. J Geol Soc 171:571-581

Cao C, Zheng Q (2009) Geological event sequences of the PermianTriassic transition recorded in the microfacies in Meishan. Sci China Ser D Earth Sci 52:1529-1536

Chan OW, Bugler-Lacap DC, Biddle JF, Lim DS, McKay CP, Pointing SB (2014) Phylogenetic diversity of a microbialite reef in a cold alkaline freshwater lake. Can J Microbiol 60:391-398

Chen J, Beatty TW, Henderson CM, Rowe H (2009) Conodont biostratigraphy across the Permian-Triassic boundary at the Dawen section, Great Bank of Guizhou, Guizhou Province, South China: implications for the Late Permian extinction and correlation with Meishan. J Asian Earth Sci 36:442-458

Ciarapica G (1990) Central and Northern Apennines during the Triassic. A review. Boll Soc Geol Ital 109:39-50

Ciarapica G, Passeri L (2000) Le facies del Triassico inferiore e medio (fm. di Monte Facito Auctt.) nelle aree di Sasso di Castalda e di Moliterno (Basilicata). Boll Soc Geol Ital 119:339-378

Ciarapica G, Passeri L (2002) The palaeogeographic duplicity of the Apennines. Boll Soc Geol Ital 121:67-75

Ciarapica G, Cirilli S, Martini R, Zaninetti L (1986) Une microfaune à petits Foraminifères d'âge permien remaniée dans le Trias moyen de l'Apennin méridional (Formation du Monte Facito, Lucanie occidentale); description de Crescentia vertebralis, n. gen. n. sp. Rev Paléobiol 5:207-215

Ciarapica G, Cirilli S, Panzanelli Fratoni R, Passeri L, Zaninetti L (1988) La Formazione di M. Facito (Appennino meridionale). In: $74^{\circ}$ Congr. S.G.I. Sorrento, pp 132-135

Ciarapica G, Cirilli S, Martini R, Panzanelli Fratoni R, Zaninetti L, Salvini Bonnard G (1990a) Reworked foraminifera in the Triassic Monte Facito Formation Auctt., Lagonegro basin (Southern Apennines, Italy). Boll Soc Geol Ital 109:143-149

Ciarapica G, Cirilli S, Martini R, Rettori R, Salvini BG, Zaninetti L (1990b) Carbonate buildups and associated facies in the Monte Facito Formation (Southern Apennines). Boll Soc Geol Ital 109:151-164

Ciarapica G, Cirilli S, Panzanelli Fratoni R, Passeri L, Zaninetti L (1990c) The Monte Facito formation (Southern Apennines). Boll Soc Geol Ital 109:135-142

Cros P (1974) Un modèle de sèdimentation carbonatée marine: les plateformes dites récifales du Trias des Dolomites et leur environnement. Ph.D thesis, État Université Paris, Paris, p 888

Delecat S, Reitner J (2005) Sponge communities from the Lower Liassic of Adnet (Northern Calcareous Alps, Austria). Facies $51: 385-404$

Donzelli G, Crescenti U (1970) Segnalazione di una microbio-facies permiana, probabilmente rimaneggiata, nella formazione di
Monte Facito (Lucania Occidentale). Boll Soc Nat Napoli 79:13-19

Dupraz C, Strasser A (2002) Nutritional modes in coralmicrobialite reefs (Jurassic, Oxfordian, Switzerland): evolution of trophic structure as a response to environmental change. Palaios 17:449-471

Emmerich A, Zamparelli V, Bechstädt T, Zühlke R (2005) The reefal margin and slope of a Middle Triassic carbonate platform: the Latemar (Dolomites, Italy). Facies 50:573-614

Enos P, Jiayong W, Yangji Y (1997) Facies distribution and retreat of Middle Triassic platform margin, Guizhou province, south China. Sedimentology 44:563-584

Enos P, Lehrmann DJ, Jiayong W, Youyi Y, Jiafei X, Chaichin DH, Minzoni M, Berri AC, Montgomery P (2006) Triassic evolution of the Yangtze platform in Guizhou Province, People's Republic of China, special paper, vol 417. Geological Society of America, pp 1-105

Ezaki Y, Liu J, Nagano T, Adachi N (2008) Geobiological aspects of the earliest Triassic microbialites along the Southern Periphery of the Tropical Yangtze platform: initiation and cessation of a microbial regime. Palaios 23:356-369

Feng Q, Gong YM, Riding R (2010) Mid-Late Devonian calcified marine algae and cyanobacteria, South China. J Paleontol 84:569-587

Finetti I, Lentini F, Carbone S, Catalano S, Del Ben A (1996) Il sistema Appenino meridionale-Arco Calabro-Sicilia nel Mediterraneo centrale: studio geologico-geofisico. Soc Geol Ital Mem 115:529-559

Flügel E (1982) Evolution of Triassic reefs current concepts and problems. Facies 6:297-328

Flügel E (1994) Pangean shelf carbonates: controls and paleoclimatic significance of Permian and Triassic reefs. In: Klein GO (ed) Pangea: paleoclimate, Tectonics, and sedimentation during accretion, zenith, and breakup of a supercontinent, special papers, vol 288. Geological Society of America, pp 247-266

Flügel E (2002) Triassic reef patterns. In: Kiessling W, Flügel E, Golonka J (eds) Phanerozoic reef patterns. SEPM Special Publications, Tulsa, pp 391-463

Flügel E (2010) Microfacies of carbonate rocks. Analysis interpretation and application. Springer Verlag Berlin Heidelberg, p 984

Fois E, Gaetani M (1984) The recovery of reef-building communities and the role of the cnidarians in carbonate sequence of the Middle Triassic (Anisian) in the Italian Dolomites. Palaeontogr Am 54:191-200

Gaetani M, Gorza M (1989) The Anisian (Middle Triassic) carbonate bank of Camorelli (Lombardy, southern Alps). Facies 21:41-56

Gaetani M, Fois E, Jadoul F, Nicora A (1981) Nature and evolution of the Middle Triassic carbonate buildups in the Dolomites (Italy). Mar Geol 44:25-57

Grădinaru E (1995) Mesozoic rocks in North Dobrogea: an overview. In: Săndulescu M, Grădinaru E (eds) IGCP Project No. 369, comparative evolution of PeriTethyan Rift Basins. Central and North Dobrogea, Romania, October 1-4, 1995. Field guidebook, Bucharest, pp 17-28

Grădinaru E (2000) Introduction to the Triassic geology of North Dobrogea Orogene. In: Grădinaru E (ed) Workshop on the Lower-Middle Triassic (Olenekian-Anisian) Boundary, 7-10 June 2000, Tulcea, Romania. Conference and field trip: Field trip guide, Bucharest, pp 5-37

Guido A, Mastandrea A, Stefani M, Russo F (2016) Role of autochthonous versus detrital micrite in depositional geometries of Middle Triassic carbonate platform systems. Geol Soc Am Bull 128:989-999 
Guido A, Russo F, Miriello D, Mastandrea A (2018) Autochthonous micrite to aphanodolomite: the microbialites in the dolomitization processes. Geosciences 8:451

Guido A, Kershaw SA, Russo F, Miriello D, Mastandrea A (2019) Application of Raman spectroscopy in comparison between cryptic microbialites of recent marine caves and Triassic patch reefs. Palaios 34:1-11

Harris MT (1993) Reef fabrics, biotic crusts and syndepositional cements of the Latemar reef margin (Middle Triassic), Northern Italy. Sedimentology 40:383-401

Harris MT (1994) The foreslope and toe-of-slope facies of the Middle Triassic Latemar buildup (Dolomites, Northern Italy). J Sediment Res 64:132-145

Harris MT (1996) The carbonate factory of Middle-Triassic buildups in the Dolomites, Italy: a quantitative analysis (discussion). Sedimentology 43:401-402

Heindel K, Foster WJ, Richoz S, Birgel D, Roden VJ, Baud A, Brandner R, Krystyn L, Mohtat T, Koşun E, Twitchett RJ, Reitner J, Peckmann J (2018) The formation of microbial-metazoan bioherms and biostromes following the latest Permian mass extinction. Gondwana Res 61:187-202

Hips K (2007) Facies pattern of western Tethyan Middle Triassic black carbonates: the example of Gutenstein Formation in Silica Nappe, Carpathians, Hungary, and its correlation to formations of adjoining areas. Sediment Geol 194:99-114

Hips K, Haas J, Poros Z, Kele S, Budai T (2015) Dolomitization of Triassic microbial mat deposits (Hungary): origin of microcrystalline dolomite. Sediment Geol 318:113-129

Keim L, Schlager W (1999) Automicrite facies on steep slopes (Triassic, Dolomites, Italy). Facies 41:15-26

Keim L, Schlager W (2001) Quantitative compositional analysis of a Triassic carbonate platform (Southern Alps, Italy). Sediment Geol 139:261-283

Kenter JAM (1990) Carbonate platform flanks: slope angle and sediment fabric. Sedimentology 37:777-794

Kershaw S (2017) Palaeogeographic variation in the Permian-Triassic boundary microbialites: a discussion of microbial and ocean processes after the end-Permian mass extinction. J Palaeogeogr 274:1-17

Kershaw S, Zhang T, Lan G (1999) A microbialite crust at the PermianTriassic boundary in South China, and its palaeoenvironmental significance. Palaeogeogr Palaeoclimatol Palaeoecol 146:1-18

Kershaw S, Guo L, Swift A, Fan J (2002) Microbialites in the PermianTriassic boundary interval in central China: structure, age and distribution. Facies 47:83-90

Kershaw S, Li Y, Crasquin-Soleau S, Feng Q, Mu X, Collin PY, Reynolds A, Guo L (2007) Earliest Triassic microbialites in the South China block and other areas: controls on their growth and distribution. Facies 53:409-425

Kershaw S, Crasquin S, Li Y, Collin PY, Forel MB, Mu X, Baud A, Wang Y, Xie S, Maurer F, Guo L (2012) Microbialites and global environmental change across the Permian-Triassic boundary: a synthesis. Geobiology 10:25-47

Kirkby MJ (1987) General models of long-term slope evolution through mass movement. In: Anderson MG, Richards KS (eds) Slope stability. Geotechnical engineering and geomorphology. Wiley, New York, pp 359-379

Lehrmann DJ (1999) Early Triassic calcimicrobial mounds and biostromes of the Nanpanjiang basin, south China. Geology 27:359-362

Lehrmann DJ, Payne JL, Pei D, Enos P, Druke D, Steffen K, Zhang J, Wei J, Orchard M, Ellwood B (2007) Record of the end-Permian extinction and Triassic biotic recovery in the Chongzuo-Pingguo platform, southern Nanpanjiang basin, Guangxi, south China. Palaeogeogr Palaeoclimatol Palaeoecol 252:200-217
Marangon A, Gattolin G, Della Porta G, Preto N (2011) The Latemar: A flat-topped, steep fronted platform dominated by microbialites and synsedimentary cements. Sediment Geol 240:97-114

Marsella E, Kozur H, D'argenio B (1993) Monte Facito Formation (Scythian-Middle Carnian). A deposit of the ancestral Lagonegro basin in the Southern Apennines. Boll Serv Geol Ital 110:225-248

Martindale RC, Foster WJ, Velledits F (2019) The survival, recovery, and diversification of metazoan reef ecosystems following the end-Permian mass extinction event. Palaeogeogr Palaeoclimatol Palaeoecol 513:100-115

Martini R, De Wever P, Zaninetti L, Denelian T, Kito N (1989) Les radiolarites triasique de la Formation du M. Facito Auctt. (Bassin de Lagonegro, Italie méridionale). Rev Paléobiol 8:143-161

Miconnet P (1988) Evolution mesozoique du secteur de Lagonegro. Soc Geol Ital Mem 41:321-330

Minzoni M, Lehrmann DJ, Dezoeten E, Enos P, Montgomery P, Berry A, Qin Y, Yu M, Ellwood BB, Payne JL (2015) Drowning of the Triassic Yangtze platform, South China, by tectonic subsidence into toxic deep waters of an anoxic basin. J Sediment Res 85:419-444

Nose M, Schmid DU, Leinfelder RR (2006) Significance of microbialites, calcimicrobes, and calcareous algae in reefal framework formation from the Silurian of Gotland, Sweden. Sediment Geol 192:243-265

Okay AI, Şengör AMC, Görür N (1994) Kinematic history of the opening of the Black Sea and its effect on the surrounding regions. Geology 22:267-270

Olivier N, Carpentier C, Martin-Garin B, Lathulliere B, Gaillard C, Ferry S, Hantzpergue P, Geister J (2004) Coral-microbialite reefs in pure carbonate versus mixed carbonate-siliciclastic depositional environments: the example of the Pagny-surMeuse section (Upper Jurassic, northeastern France). Sediment Geol 205:14-33

Palladino G (2015) Determining the way-up of the Monte Facito Formation using new sedimentological data from the "La Cerchiara" succession, Southern Apennines. Ital J Geosci 134:120-133

Palladino G, Prosser G, Bentivenga M, Alsop G (2019) Mass transport deposits overprinted by contractional tectonics: a case study from the southern Apennines of Italy. Geol Mag 156:849-873

Panzanelli Fratoni R (1991) Analisi stratigrafica della "Formazione del M. Facito" Auctt. Proposta di istituzione del Gruppo di Monte Facito (Tesi di Dottorato in Scienze della Terra). Ph.D thesis, Università degli Studi di Perugia, Perugia

Panzanelli Fratoni R, Limongi P, Ciarapica G, Cirilli S, Martini R, Bonnard GS, Zaninetti L (1987) Les foraminifères du Permien superieur remaniés dans le "Complex terrigène" de la Formation triasique du M. Facito, Apennin méridional. Rev Paléobiol 6:293-319

Passeri L, Ciarapica G (2010) Le litofacies permiane e triassiche della formazione di M. Facito auctt. nell'area di M. Facito (successione di Lagonegro, Appennino meridionale). Ital J Geosci 29:29-50

Patacca E, Scandone P, Bellatalla M, Perilli N, Santini U (1992) La zona di giunzione tra l'arco appenninico settentrionale e l'arco appenninico meridionale nell'Abbruzzo e nel Molise. Studi Geologici Camerti, volume speciale CROP 11:417-441

Patacca E, Scandone P (2007) Geology of the Southern Apennines. In: Mazzotti A, Patacca E, Scandone P (eds) Results of the CROP project, sub-project CROP-04 Southern Apennines (Italy), vol 7. Bollettino- Societa Geologica Italiana Special Publications, pp 75-119

Payne JL, Lehrmann DJ, Christensen S, Wei J, Knoll AH (2006) Environmental and biological controls on the initiation and growth of 
a Middle Triassic (Anisian) reef complex on the Great Bank of Guizhou, Guizhou Province, China. Palaios 21:325-343

Payne JL, Summers M, Rego BL, Altiner D, Wei J, Yu M, Lehrmann DJ (2011) Early and Middle Triassic trends in diversity, evenness, and size of foraminifers on a carbonate platform in south China: implications for tempo and mode of biotic recovery from the end-Permian mass extinction. Paleobiology 37:409-425

Popa L, Panaiotu CE, Grădinaru E (2014) An early Middle Anisian (Middle Triassic) Tubiphytes and cement crusts-dominated reef from North Dobrogea (Romania): facies, depositional environment and diagenesis. Acta Geol Pol 64:189-206

Pruss SB, Bottjer DJ, Corsetti FA, Baud A (2006) A global marine sedimentary response to the end-Permian mass extinction: examples from southern Turkey and the western United States. Earth Sci Rev 78:193-206

Reitner J, Neuweiler F (1995) Mud mounds: a polygenetic spectrum of fine-grained carbonate buildups. Facies 32:1-70

Rettori R, Ciarapica G, Cirilli S, Martini R, Salvini Bonnard G, Zaninetti LE (1988) Build-ups ladinici e facies associate nella Formazione di M. Facito (Appennino Meridionale). In: Atti del $74^{\circ}$ congresso della società geologica Italiana

Russo F (2005) Biofacies evolution in the Triassic platforms of the Dolomites, Italy. Ann Univ Ferrara 2005:33-43

Russo F, Neri C, Mastandrea A, Baracca A (1997) The mud-mound nature of the Cassian platform margins of the Dolomites. A case history: the Cipit boulders from Punta Grohmann (Sasso Piatto Massif, northern Italy). Facies 36:25-36

Russo F, Mastandrea A, Stefani M, Neri C (2000) Carbonate facies dominated by syndepositional cements: a key component of Middle Triassic platforms. The Marmolada case history (Dolomites, Italy). Facies 42:211-226

Saint-Martin JP, Müller P, Moissette P, Dulai A (2000) Coral microbialite environmnet in a Middle Miocene reef of Hungary. Palaeogeogr Palaeoclimatol Palaeoecol 160:179-191

Sánchez-Beristain F, Reitner J (2019) Microbialite-dominated fossil associations in Cipit boulders from Alpe di Specie and Misurina (St. Cassian Formation, Middle to Upper Triassic, Dolomites, NE Italy). TIP Rev Espec Cienc Químico-Biol 22:1-18

Săndulescu M (1995) Dobrogea within the Carpathian Foreland. In: Săndulescu M, Grădinaru E (eds) IGCP Project No. 369, comparative evolution of PeriTethyan Rift Basins. Central and North Dobrogea, Romania, October 1-4, 1995. Field guidebook, Bucharest, pp 1-4

Scandone P (1967) Studi di geologia lucana: la serie calcareo-silicomarnosa e i suoi rapporti con l'Appennino Calcareo. Boll Soc Nat Napoli 76:301-469

Scandone P (1972) Studi di geologia lucana: carta dei terreni della serie calcareo-silico-marnosa e note illustrative. Boll Soc Nat Napoli 81:225-300

Schlager W (2003) Benthic carbonate factories of the Phanerozoic. Int J Earth Sci 92:445-464

Schlager W, Keim L (2009) Carbonate platforms in the Dolomites area of the Southern Alps-historic perspectives on progress in sedimentology. Sedimentology 56:191-204

Schlager W, Reijmer JJG (2009) Carbonate platform slopes of the Alpine Triassic and the Neogene: a comparison. Mitt Österr Geol Ges 102:4-14

Scotese C, Schettino A (2017) Late Permian-early Jurassic paleogeography of Western Tethys and the World. In: Soto JI, Flinch JF, Tari G (eds) Permo-Triassic salt provinces of Europe, North Africa and the Atlantic margins. Elsevier, pp 57-95

Seeling M, Emmerich A, Bechstädt T, Zühlke R (2005) Accommodation/sedimentation development and massive early marine cementation: Latemar vs. Concarena (Middle/Upper Triassic, Southern Alps). Sediment Geol 175:439-457
Senowbari-Daryan B, Zühlke R, Bechstadt T, Flügel E (1993) Anisian (middle triassic) buildups of the Northern Dolomites (Italy): the recovery of reef communities after the permian/triassic crisis. Facies 28:181-256

Shapiro R (2004) Neoproterozoic-Cambrian microbialite record. Paleontol Soc Pap 10:5-16

Sheehan PM (1985) Reefs are not so different-they follow the evolutionary pattern of the level-bottom communities. Geology 13:46-49

Sheehan PM, Fagerstrom JA (1988) The evolution of reef communities. Palaios 3:251-252

Stampfli GM, Borel GD (2002) A plate tectonic model for the Paleozoic and Mesozoic constrained by dynamic plate boundaries and restored synthetic oceanic isochrons. Earth Planet Sci Lett 196:17-33

Stanley GD (1988) The history of early Mesozoic reef communities: a three-step process. Palaios 3:170-183

Stefani M, Furin S, Gianolla P (2010) The changing climate framework and depositional dynamics of Triassic carbonate platforms from the Dolomites. Palaeogeogr Palaeoclimatol Palaeoecol 290:43-57

Szulc J (2002) Recovery of the reef-forming sponge-microbial assemblages after the P/T crisis and their role in reefs evolution in early-middle Triassic times. In: IUGS Subcomission on triassic stratigraphy (ed), STS/IGCP 467 field meeting, Veszprem, Hungary, pp 58-60

Török Á (1998) Controls on development of Mid Triassic ramps: examples from southern Hungary. Carbonate ramps. J Geol Soc London Spec Publ 149:339-367

Tosti F, Guido A, Demasi F, Mastandrea A, Russo F (2011) Biogeochemical characterization of automicrites building the Cipit boulders of the Ladinian-Carnian platforms in the Dolomites (northeastern Italy). Rend Soc Geol Ital 17:179-183

Tosti F, Guido A, Mastandrea A, Demasi F, Russo F (2012) Rare earth elements signature in Triassic samples from Punta Grohmann and Alpe di Specie (Dolomites, Italy): evidence of cyanobacterial vs sulfate reducing bacteria metabolic activities. Rend Soc Geol Ital 21:943-944

Tosti F, Mastandrea A, Guido A, Demasi F, Russo F, Riding R (2014) Biogeochemical and redox record of mid-late Triassic reef evolution in the Italian Dolomites. Palaeogeogr Palaeoclimatol Palaeoecol 399:52-66

Tunis G, Pugliese N, Jurkovšek B, Ogorelec B, Drobne K, Riccamboni R, Tewari VC (2011) Microbialites as markers of biotic and abiotic events in the Karst District, Slovenia and Italy. In: Tewari V, Seckbach J (eds) Stromatolites: interaction of microbes with sediments: cellular origin, life in extreme habitats and astrobiology, vol 18. Springer, Dordrecht, pp 251-272

Turner EC, Narbonne GM, James NP (2000) Framework composition of early Neoproterozoic calcimicrobial reefs and associated microbialites, MacKenzie Mountains, N.W.T., Canada. In: Grotzinger JP, James NP (eds) Carbonate sedimentation and diagenesis in the evolving precambrian world, special publication, vol 67. SEPM, pp 179-205

van Hinsbergen DJJ, Torsvik TH, Schmid SM, Mațenco LC, Maffione M, Vissers RLM, Gürer D, Spakman W (2020) Orogenic architecture of the Mediterranean region and kinematic reconstruction of its tectonic evolution since the Triassic. Gondwana Res 81:79-229

Velledits F (1999) A triász zátonyok fejlődésének áttekintése. Földt Közlöny 129:249-267

Velledits F (2008) Evolution of the Triassic reef communities. In: Galácz A (ed) 125th Anniversary of the Department of Palaeontology at Budapest University-a jubilee, vol 6. Hantkeniana, pp 9-16 
Velledits F, Péró C, Blau J, Senowbari-Daryan B, Kovács S, Piros O, Pocsai T, Szügyi-Simon H, Dumitrică P, Pálfy J (2011) The oldest Triassic platform margin reef from the Alpine-Carpathian Triassic, Aggtelek, NE Hungary. Riv Ital Paleontol Stratigr 117:221-268

Wahlman GP, Orchard DM, Buijs DM (2013) Calcisponge-microbialite reef facies, middle Permian (lower Guadalupian), northwest shelf margin of Permian Basin, New Mexico. Am Assoc Pet Geol Bull 97:1895-1919

Webb GE (1996) Was Phanerozoic reef history controlled by the distribution of non-enzymatically secreted reef carbonates (microbial carbonate and biologically induced cement)? Sedimentology 43:947-971

Westphal H, Heindel K, Brandano M, Peckmann J (2010) Genesis of microbialites as contemporaneous framework components of deglacial coral reefs, Tahiti (IODP 310). Facies 56:337-352
Wood AW (1981) Extensional tectonics and the birth of the Lagonegro Basin (Southern Italian Apennines). Neues Jahrb Geol Paläontol Abh 161:93-131

Wood R (1999) Reef evolution. Oxford University Press, Oxford, p 426

Wood R (2001) Are reefs and mud mounds really so different? Sediment Geol 145:161-171

Zamagni J, Košir A, Mutti M (2009) The first microbialite - coral mounds in the Cenozoic (Uppermost Paleocene) from the Northern Tethys (Slovenia): environmentally-triggered phase shifts preceding the PETM? Palaeogeogr Palaeoclimatol Palaeoecol 274:1-17

Zhuravlev AY (1996) Reef ecosystem recovery after the Early Cambrian extinction. In: Hart MB (ed) Biotic recovery from mass extinction events, vol 102. Geological Society London, pp 79-96 